\title{
LAND-OCEAN CONTRIBUTIONS OF ARSENIC THROUGH A RIVER-ESTUARY-RIA SYSTEM (SW EUROPE) UNDER THE INFLUENCE OF ARSENOPYRITE DEPOSITS IN THE FLUVIAL BASIN
}

\author{
Marta Costas ${ }^{1}$, Ricardo Prego ${ }^{2 *}$, Ana V. Filgueiras ${ }^{2}$ and Carlos Bendicho ${ }^{1}$ \\ ${ }^{1}$ Dept. de Química Analítica y Alimentaria. Faculty of Chemistry (UVigo). Campus de Vigo. 36310 Vigo, Spain. \\ ${ }^{2}$ Marine Research Institute (IIM-CSIC). Eduardo Cabello, 6. 36208 Vigo, Spain. \\ *corresponding autor: prego@iim.csic.es; fax: +34986292762
}

\begin{abstract}
Water was sampled monthly from September 2005 to August 2006 at 14 stations distributed throughout the coastal system of Anllóns-Laxe, from where 30 surface sediment samples were also taken. After filtration through $0.22 \mu \mathrm{m}$ polycarbonate filters, dissolved inorganic and total arsenic (UV oxidation) concentration was determined by HG-AFS. After microwave digestion, the arsenic in SPM and sediment was determined by AAS. Ultra-clean procedures were adopted during sampling, handling and analysis and the analytical accuracy was checked using CRM. Spatial distribution of As in water (0.2-4.0 $\left.\mu \mathrm{g} \cdot \mathrm{L}^{-1}\right), \mathrm{SPM}\left(21-169 \mathrm{mg} \cdot \mathrm{kg}^{-1}\right)$ and sediment of the river reservoir was altered by the presence of arsenopyrite deposits in the middle fluvial basin that increases $2.1 \pm 0.5$ and $1.7 \pm 0.5$ times the concentrations of inorganic dissolved (DI-As) and particulate (P-As) arsenic, respectively. At the termination fluvial zone As fluxes can be calculate to be: $[\mathrm{DI}-\mathrm{As}]=7.09 \cdot \mathrm{Q}^{-0.69}$. The Anllóns River exports to its estuary $460 \mathrm{~kg} \cdot \mathrm{a}^{-1}$ of dissolved $\left(<7 \%\right.$ as organic) arsenic annually. It is higher (i.e. $0.83 \mathrm{~kg} \cdot \mathrm{s}^{-1} \cdot \mathrm{km}^{-2}$ of DI-As) than that of most of European rivers. In the estuary reservoir, the influence of arsenopyrite is also evident as the river concentration of DI-As, which was lower than in seawater during the wet season and higher during the dry season. Arsenic has non-conservative behaviour, as in other European estuaries, but the Anllóns shows an ambivalent pattern: as it usually gain DI-As during the wet season and loses it during the dry season, while P-As seems to behave contrary to the DI-As. When the fluvial arsenic reaches the ria its concentration varies due to the estuarine processes. In the wet season DI-As increases its concentration by one third while in the dry season it decreases by one fifth and the annual contribution to the ria is $10 \%$ higher than the fluvial output. In the case of P-As more data are necessary to quantify its behaviour; however, the estuarine sediments are contaminated by arsenic. In the ria reservoir DI-As levels were similar to those of the ocean, DO-As comprises 9$22 \%$ of the inorganic, P-As ranges from 3 to $40 \mathrm{mg} \cdot \mathrm{kg}^{-1}$, and As-sedimentary can classified as uncontaminated (4-18 $\left.\mathrm{mg} \cdot \mathrm{kg}^{-1}\right)$, except in the fishering ports. The ria circulation, reinforced by upwelling favours the exportation of arsenic to the ocean. In the Anllóns-Laxe system as a whole, the freshwater-saline interface processes do not lead to a decrease in the dissolved fluvial arsenic flux to the ocean.
\end{abstract}

Keywords: arsenic, water, suspended particulate matter, sediment, fluxes, Spain. 


\section{INTRODUCTION}

Arsenic is a ubiquitous element in nature. In abundance, it is ranked twentieth in the earth's crust which contains 1-2 mg $\mathrm{kg}^{-1}$ of arsenic (Matschullat, 2000). This chalcophile element is concentrated in a variety of ores in over 200 different mineral forms of which arsenopyrite is its most abundant (Sanders, 1980). During the transport of arsenic from rock and mineral weathering various different reservoirs are involved: rock, soil, river, estuary, coastal zones and ocean, i.e. from the local to the global scale. The studies of arsenic in the hydrosphere usually consider only one of these reservoirs but do not consider them as a whole. The coastal management initiatives emphasizes that the water continuum of a river basin catchment and its receiving adjacent ocean is a fundamental unit for coastal assessment and management (Crossland et al., 2005). Accordingly, the quantification of arsenic fluxes in the land-sea exchange would permit an arsenic balance to be constructed and elucidate the importance of arsenic sources and sinks. If the anthropogenic contamination is disregarded, the type of parent rock is a much more important factor controlling soil arsenic contents than is the soil type (Mandal and Suzuki, 2002).

According to Sherrell and Ross (1999), three broad mechanisms can be distinguished: changes in the hydrological flow path at high discharge, exchanges between bed load or suspended particles and the dissolved phase and discharge of arsenic due to human activities. The products of rocks and soil degradation and erosion are transported by surface waters (Matschullat, 1996) towards the estuaries and the behaviour of arsenic in the estuarine environment has still received comparatively little attention (Howard et al., 1988). In this environment, the changes of physicochemical conditions may favour arsenic mobilization or sedimentation. The flocculation of iron oxides in the estuary as a result of the increase in $\mathrm{pH}$ and salinity can cause a decrease in the arsenic flux to the ocean (Cullen and Reimer, 1989); however, a change in the surface chemistry of the iron oxides during early diagenesis may be an important factor in arsenic desorption (Smedley and Kinniburgh, 2002). Studied estuarine systems can be divided into those in which the principal arsenic input is of marine origin (Waslenchuk and Windom, 1978; Howard et al., 1984; Froelich et al., 1985) and those in which rivers are the major source of arsenic (Andreae et al., 1983; Knox et al., 1984; Millward and Marsh, 1986). The entire ria can not be considered as an estuary because rias are flooded incised valleys where only the inner part are estuarine from both hydrographic and sedimentological considerations (Evans and Prego, 2003). Therefore, the main estuarine processes are confined to its inner relatively small brackish water zone. The arsenic behaviour in ria-type of coastal systems has not yet been properly studied (Prego and Cobelo-García, 2003).

In the Galician Rias arsenic and its speciation was studied in the marine sediments of La Coruña Bay (Gonzalez-Soto et al., 1996) and, together with other metals, in the Ria of Vigo (Rubio et al., 2000) while dissolved arsenic concentrations were only measured in the Ria of Arousa (Peña-Vázquez et al., 2006). Although dissolved arsenic concentration in open-ocean is relatively constant, continental anthropogenic or geological additions of arsenic could increase the concentration of dissolved and particulate arsenic in the shelf. However, as observed in other estuaries (Millward and Glegg, 1997; Balci, 1999; Helland, 2001), the Galician Rias are assumed to behave as depositional frontiers of some trace elements (Prego and Cobelo-García, 2003), this is why it can be hypothesised that rias may behave as an arsenic barrier and it may accumulate in their sediments.

The focus of this study is to explore the river-ocean pattern of arsenic exportation through the continuum river-estuary-ria, with special attention to the role of estuary in the water and sediment transport. As this pattern could be affected by the local presence of arsenopyrite in the middle fluvial basin, a secondary aim is to investigate the significance of a lithological alteration along the whole fluvial-coastal system and to investigate the hypothesis that the processes in the freshwater-salinity interface can lead to a major decrease in the arsenic flux to the ocean (Cullen and Reimer, 1989). To achieve these two objectives the spatial and temporal arsenic distribution and enrichment in waters, suspended particulate matter and surface sediments of Anllóns River, its estuary and the Ria of Laxe have been investigated; in the same way the dissolved and 
particulate arsenic behaviour during the estuarine mixing are studied; finally, the annual fluxes and load of arsenic transported by the River to the Ria are estimated. Such information is necesary as was stressed by Plant et al. (2003), who remarked the need for more geochemical and hydrochemical surveys on arsenic and thereby acquire a much better picture of their distribution, behaviour, and role in the environment.

\section{MATERIAL AND METHODS}

\subsection{Coastal System description}

The Anllóns River (Fig.1) is $60 \mathrm{~km}$ in length and runs into the Ria of Laxe. This river has a natural regime (without dam) with an annual average flow of $11.9 \mathrm{~m}^{3} \cdot \mathrm{s}^{-1}$ (Labandeira et al., 2001; Rivas et al., 2007). The River is in a wet temperate oceanic climate zone (Cfb Köppen type) and yearly variations between extreme discharges may reach from $80 \mathrm{~m}^{3} \cdot \mathrm{s}^{-1}$ during the rainy season to $1 \mathrm{~m}^{3} \cdot \mathrm{s}^{-1}$ in the dry period. River floods are very unusual; only four cases of discharges higher than $100 \mathrm{~m}^{3} \cdot \mathrm{s}^{-1}$ has been recorded since 1971 .

The fluvial basin covers a surface area of $516 \mathrm{~km}^{2}$ with a population density of 80 inhabitants per $\mathrm{km}^{2}$. In the towns of Carballo (18,100 inhabitants), at river head, and Ponteceso $(6,800$ inhabitants), on the estuary, sewage works pour effluent into the system. The hinterland is dedicated to agriculture and cattle raising. The Anllóns catchment is comprised of metamorphic (schist and gneisses) and basic rocks with alluvial deposits in the stretches of the lower river. However, in the middle course, the river flows through an area of high grade mineralization which consists of grey to bluish quartz veins containing disseminated and strings of arsenopyrite (3-10\%) enclosed in larger zones of silicified rocks (IGME, 1981a). In this mineralized zone there is the small area of gold mining at Corcoesto, which has been occasionally exploited from the Roman times to the second decade of 20th century. Shafts of $100 \mathrm{~m}$ depth and $3 \mathrm{~m}$ diameter are common in the disused Corcoesto area (Mirre, 1990).

The Ria of Laxe (Fig.1) has a surface area of $24 \mathrm{~km}^{2}$ and contains a volume of $0.38 \mathrm{~km}^{3}$ of water. This ria is oriented in a NW-SE direction and converges to the mouth of the Anllóns River in its innermost part. Ria mouth is $4.9 \mathrm{~km}$ wide and has a maximum depth of $36 \mathrm{~m}$. On the basis of topography, the Ria may be considered as an open bay with a strong oceanic influence, especially during the upwelling season (Varela et al., 2005). The ria has a prevailing seaward flow near its northern coast with surface currents between 5 and $20 \mathrm{~cm} \cdot \mathrm{s}^{-1}$ (Labandeira et al., 2001). The Ria has two small fishing ports: Laxe (3,600 inhabitants) and Corme (1,300 inhabitants). Ten mussel mariculture rafts are anchored in the Corme inlet and clams and cockles are cultured on the narrow estuarine flat, which is separated from the Ria by a sand bar of $2 \mathrm{~km}$ length.

\subsection{Sampling and sample treatment}

\subsubsection{Water samples}

Water samples were taken in fourteen sites distributed throughout the river and estuary of the Anllóns and the Ria of Laxe. Six stations (st. A-F, Fig.1) were situated in the River, five (st. G-K, Fig.1) in the estuary and three (st. L-N, Fig.1) along the margins of the Ria. Each water sampling was repeated each month from September 2005 to August 2006 (dates in Fig.2). Samples were collected in such a way that brackish water sampling in the estuary coincided with low tide (the tidal range during the sampling days was similar: $2.6 \pm 0.3 \mathrm{~m}$ ).

Water samples were collected in low density polyethylene $1 \mathrm{~L}$ bottles (acid washed) by means of a telescopic plastic bar at 3-4 $\mathrm{m}$ from the bank and at a depth of $0.2 \mathrm{~m}$ and put inside a portable fridge $\left(4^{\circ} \mathrm{C}\right)$. Salinity, temperature and $\mathrm{pH}$ were measured in situ using a calibrated F/SET3 WTW Mutiline-4. Samples for dissolved oxygen determination were taken in $140 \mathrm{~mL}$ glass bottles and stored in the dark until next day when they were analyzed.

The water samples were vacuum filtered through $0.22 \mu \mathrm{m}$ polycarbonate filters (acidwashed) in a Nalgene system within 12 hours of sampling. Filtrations were carried out inside a class-100 horizontal laminar flow clean bench (CRUMA, 670-FL model) in an ultra-clean laboratory 
(class-1000). The subsequent filtrate was stored in LDPE bottles, acidified to $\mathrm{pH} 2$ ( $\mathrm{HCl}$ Suprapur) and stored in the dark at $4^{\circ} \mathrm{C}$ until analysis of dissolved inorganic arsenic. In the case of total dissolved arsenic, $\mathrm{NaOH}$ dissolution was added to the filtered water sample up to $\mathrm{pH} 11$ and 35 $\mathrm{mL}$ was then oxidised in a digestion quartz tube under UV radiation (Castro et al., 2007). Finally, oxidised samples were acidified to $\mathrm{pH} 2(\mathrm{HCl}$ Suprapur) and was analyzed for arsenic.

The filters containing the suspended particulate matter (SPM) were dried at room temperature; then, the SPM content was quantified by determining the difference to the filter weight. From the filtered water volume and the SPM weight, the SPM concentration was calculated. Filters with SPM were stored deeply frozen inside Petri dishes. After, SPM samples were microwave digested (Milestone 1200 Mega) in Teflon bombs using a $\mathrm{HNO}_{3} 65 \% \mathrm{v} / \mathrm{v}$ and $\mathrm{HF}$ $48 \% \mathrm{v} / \mathrm{v}$ mixture following the EPA 3052 guideline (USEPA, 1996). Clean procedures were adopted during sampling, handling and analysis. Water and SPM filter blanks were obtained following the same procedure as with the samples.

Daily flow data of the Anllóns River were supplied by the 'Aguas de Galicia' company. The flows were measured at the gauging station number 0485 (438 $\mathrm{km}^{2}$ of fluvial basin). The flows were area-corrected to estimate that from the whole river basin area.

\subsubsection{Sediment samples}

Thirty surface sediment samples were collected using Van Veen grab samplers: twelve (st. 19-30, Fig.1) in the Ria of Laxe from the R/V Mytillus; twelve (st. 7-18, Fig.1) in the Anllóns estuary using the R/V Mytilus auxiliary boat Zoea and six (st. 1-6, Fig.1) in the Anllóns River by hand (April 2006). Only the top $1 \mathrm{~cm}$ layer of the sediment was taken, stored in hermetically closed polyethylene vials and kept in a cooler at $4^{\circ} \mathrm{C}$. Later, samples were dried in an oven $\left(<40^{\circ} \mathrm{C}\right)$ and then sieved through Retsch meshes in order to obtain the fraction lower than $63 \mu \mathrm{m}$. This fine fraction of the sediments were microwave digested (Milestone 1200 Mega) using a procedure as with the SPM. Handling and analysis samples were carried out in an ultra-clean laboratory. All PE material employed for sampling, storage and sample treatment was previously acid-washed with $\mathrm{HNO}_{3} 10 \% \mathrm{v} / \mathrm{v}$ for $24 \mathrm{~h}$ and rinsed throughout with ultrapure Milli-Q water.

\subsection{Analysis}

\subsubsection{Water samples}

Dissolved inorganic and total arsenic concentrations were determined by means of hydride generation atomic fluorescence spectrometry using a PS Analytical Millenium System. Arsine generation was carried out using a chemifold, a gas-liquid separator made of glass and two peristaltic pumps. Argon was used as carrier gas in the gas-liquid separator. Concentration of dissolved organic arsenic was calculated subtracting the dissolved inorganic arsenic content from the total dissolved measured value of this element.

The accuracy of the analytical procedure for the analysis of arsenic in waters was checked using recoveries. Good recoveries was found in fluvial, estuarine and coastal waters $(98 \pm 2 \%$, $93 \pm 5 \%$ and $97 \pm 2 \%$, respectively) to the inorganic arsenic while the total arsenic was validated with BCR 403 (Certificate Reference Material: $1.43 \pm 0.21 \mu \mathrm{g} \cdot \mathrm{L}^{-1}$ of As), that was similar to the obtained: $1.50 \pm 0.20 \mu \mathrm{g} \cdot \mathrm{L}^{-1}$ of As. The limit of detection (LOD) calculated as three times the standard deviation of the blank ( $3 \sigma$ criterion) was $0.11 \mu \mathrm{g} \cdot \mathrm{L}^{-1}$. The precision of the method, expressed as the relative standard deviation (\% RSD) was evaluated in terms of repeatability and reproducibility. Repeatability value (ten replicates measurements at the same day) was $4.7 \%$ and reproducibility value (three replicates measurements in ten different days) was $10.0 \%$.

Dissolved oxygen concentrations were measured on next day after sampling by Winkler titration of samples to calculate saturation percentages (Aminot, 1983). The error was calculated in $0.4 \%$ by analyzing samples of the same fresh-, brackish- or sea-water ten times.

\subsubsection{Sediment and SPM samples}


After microwave digestion, arsenic in SPM and sediments was determined by means of Electrothermal Atomic Absorption Spectrometry using a Varian 220 apparatus equipped with Zeeman background correction. The LOD ( $3 \sigma$ criterion) was $1.8 \mathrm{mg} \cdot \mathrm{kg}^{-1}$. The repeatability value (ten replicates, the same day) was $2.4 \%$ and reproducibility value (three replicates, ten different days) was $8.0 \%$. The accuracy of the analytical procedure was checked using the PACS-2 (NRCC, Canada) certified reference material. Agreement with the certified value was appropriate: $28.1 \pm 2.8 \mathrm{mg} \cdot \mathrm{kg}^{-1}$ measured versus $26.2 \pm 1.5 \mathrm{mg} \cdot \mathrm{kg}^{-1}$ certified arsenic range.

Aluminium and iron were determined in surface sediments by means of Flame Atomic Absorption Spectrometry (FAAS) using a Varian 220-FS apparatus. LOD ( $3 \sigma$ criterion) of Al was $0.08 \mathrm{~g} \cdot \mathrm{kg}^{-1}$, its repeatability value (ten replicates, the same day) was $2.8 \%$ and its reproducibility value (three replicates, ten different days) was $8.9 \%$. The accuracy was checked using the CRM PACS-2: concentration measured of Al $\left(61.9 \pm 2.4 \mathrm{~g} \cdot \mathrm{kg}^{-1}\right)$ and Fe $\left(42.3 \pm 1.3 \mathrm{~g} \cdot \mathrm{kg}^{-1}\right)$ were in agreement with their certified values, $66.1 \pm 5.3$ and $40.9 \pm 0.6 \mathrm{~g} \cdot \mathrm{kg}^{-1}$, respectively.

\section{RESULTS}

\subsection{The major variables}

The Anllóns discharge varied from 0.7 to $80.2 \mathrm{~m}^{3} \cdot \mathrm{s}^{-1}$ during the hydrological year of October 2005 - September 2006 (Fig.2). In the studied period, the maximum discharges were observed in the months of February-April and the minimum in August-September. These did not rigorously follow the general trend of maximum precipitation values in the December-February interval due to changes in rain patterns over the river catchment area. However, the average volume in the Anllóns River during the sampling hydrological year was $10.2 \mathrm{~m}^{3} \cdot \mathrm{s}^{-1}$, that is within the range of the last 30 years: $11.3 \pm 2.5 \mathrm{~m}^{3} \cdot \mathrm{s}^{-1}$. In the whole river-ria system, according to the values shown in the Table 1, the salinity permits the definition of three parts (Fig.1): the fluvial, stations A-F; the estuarine, stations G-J, with a salinity range of 0.1-30; and the ria (st. K-N), an open bay under sea influence. The highest values of salinity in the estuary coincided with lowest river contributions of freshwater in summer; on the contrary, the lowest salinities occurred at high Anllóns discharges in winter. For this reason, stations at the section boundaries, i.e. stations $G$ and $K$, have a lower salinity during the wet season and can be occasionally included inside the fluvial part.

Water temperature fluctuated during the studied period from 6.9 to $20.7^{\circ} \mathrm{C}$ in the river, from 6.9 to $24.4^{\circ} \mathrm{C}$ in the estuary and from 11.0 to $18.7^{\circ} \mathrm{C}$ in the ria stations. These fluctuations are in agreement with the usual values of a temperate coastal area. Station $\mathrm{H}$ showed the lowest and highest water temperature during the samplings, $6.9^{\circ} \mathrm{C}$ in February and $24.4^{\circ} \mathrm{C}$ in July. The river water were slightly basic with the $\mathrm{pH}$ varying from 7.2 to 7.6 , the ria seawater ranged from 8.1 to 8.3 whilst in the estuary $\mathrm{pH}$ values were between these values (7.2-8.3).

Oxygen saturation in the river waters (st. F) varied from $100 \%$ in winter to $93 \%$ in early autumn whilst in the estuary (st. $\mathrm{H}$ ) the range was higher, $113-80 \%$ in surface brackish waters and 99-75\% near the bottom, where the lowest percentages of oxygen were recorded in summer. In the ria seawater oxygen concentrations were not measured but results from Varela et al. (2005) from the middle ria indicated a similar trend to that in the estuary: oxygen saturation rising to $115 \%$ in the surface waters of the ria during upwelling events (spring-summer) and falling to $75 \%$ near the bottom in November.

Suspended particulate matter (SPM) in the fluvial part showed the typical increase of load with the river discharge. In the sampling flow range of $1-24 \mathrm{~m}^{3} \cdot \mathrm{s}^{-1} \mathrm{SPM}$ varied with discharge (Fig.3), i.e. at station A (Fig.1) from $12 \mathrm{mg} \cdot \mathrm{L}^{-1}$ at $2 \mathrm{~m}^{3} \cdot \mathrm{s}^{-1}$ to $65 \mathrm{mg} \cdot \mathrm{L}^{-1}$ at $24 \mathrm{~m}^{3} \cdot \mathrm{s}^{-1}$. In the estuary SPM concentrations were lower ranging from 5 to $30 \mathrm{mg} \cdot \mathrm{L}^{-1}$. In the ria waters the SPM varied from 2 to $33 \mathrm{mg} \cdot \mathrm{L}^{-1}$; with the maximum occurring in March, probably associated with the phytoplankton spring bloom (Varela et al., 2005). On the other hand, the fine fraction of the sediments, i.e. the fraction lower than $63 \mu \mathrm{m}$, was $8.5 \pm 6.0 \%$ in the river, $26.1 \pm 9.2 \%$ in the estuary and $0.9 \pm 0.6 \%$ in the ria. 


\subsection{Dissolved arsenic in waters}

The concentrations of dissolved inorganic arsenic (DI-As) in the Anllóns River, its estuary and the Ria of Laxe are shown in Table 2. Arsenic ranged from 0.16 to $3.96 \mu \mathrm{g}^{-1} \mathrm{~L}^{-1}$ in the river freshwater, from 0.52 to $2.95 \mu \mathrm{g} \cdot \mathrm{L}^{-1}$ in the estuarine brackishwater and from 0.30 to $2.60 \mu \mathrm{g} \cdot \mathrm{L}^{-1}$ in the ria seawater. In this coastal system the variability of arsenic levels $\left(0.1-4.0 \mu \mathrm{g} \cdot \mathrm{L}^{-1}\right)$ is associated with local and temporal changes.

A spatial variation, based in the annual average values of each sampling station, was observed from the river to the ria. So, in the upper river zone (A-C stations: $0.9 \mu \mathrm{g} \cdot \mathrm{L}^{-1}$ ) the DI-As was lower than concentrations in the middle river zone (D-F stations: $1.8 \mu \mathrm{g} \cdot \mathrm{L}^{-1}$ ). Where, the lithology changes from the granite and schist of Anllóns upper basin to the area of quartz veins containing arsenopyrite enclosed in larger zones of silicification. In the estuary (G-K stations: 1.4 $\mu \mathrm{g} \cdot \mathrm{L}^{-1}$ ), the DI-As decreased and were similar to those measured in the ria (L-N stations: $1.5 \mu \mathrm{g} \cdot \mathrm{L}^{-}$ ${ }^{1}$ ). Monthly data showed that for each month in the fluvial zone upstream and downstream of the Corcoesto zone (Table 2), the annual average of DI-As increases $2.1 \pm 0.5$ times in the Anllóns River due to the influence of arsenopirite.

The pattern of DI-As is flow dependent, following the trend shown in Fig.4: the arsenic content decreases when the fluvial discharge increases and vice versa. In the estuary the same seasonal trend was detected varying from $2.6 \mu \mathrm{g} \cdot \mathrm{L}^{-1}$ in August to $0.9 \mu \mathrm{g} \cdot \mathrm{L}^{-1}$ in February. In the ria seawater, the behaviour was different, DI-As oscillated between maximum concentrations in January $\left(2.0 \mu \mathrm{g} \cdot \mathrm{L}^{-1}\right)$ and in May $\left(2.4 \mu \mathrm{g} \cdot \mathrm{L}^{-1}\right)$ and minimum levels $\left(0.5-0.8 \mu \mathrm{g} \cdot \mathrm{L}^{-1}\right)$ in October, December and April.

Dissolved organic arsenic (DO-As) concentrations were measured in March, May and August at stations $\mathrm{F}$ (river), $\mathrm{H}$ (estuary) and $\mathrm{N}$ (ria). In the fluvial and brackish waters DO-As was lower than the limit of detection $\left(0.11 \mu \mathrm{g} \cdot \mathrm{L}^{-1}\right)$, and no significant variations were observed in the total dissolved arsenic. In coastal waters, DO-As ranged between 0.17 and $0.58 \mu \mathrm{g} \cdot \mathrm{L}^{-1}$. The highest percentage of the total dissolved arsenic occurred in May (22\%) while during the other two occasions was $9 \%$.

\subsection{Arsenic in the suspended particulate matter}

The concentrations of particulate arsenic in SPM (P-As) of the waters of the Anllóns River, its estuary and the Ria of Laxe are indicated in Table 3. Values of P-As were in the range of 33-169 $\mathrm{mg} \cdot \mathrm{kg}^{-1}$ in the river, $16-308 \mathrm{mg} \cdot \mathrm{kg}^{-1}$ in the estuary and $3-198 \mathrm{mg} \cdot \mathrm{kg}^{-1}$ in the ria. Arsenic contents in the SPM increased progressively from the upper to the middle river section, i.e. from st. $A$ to the gauging station (st. F) where P-As can double. However, in August the highest P-As was recorded in the Corcoesto area (station D: $181 \mathrm{mg} \cdot \mathrm{kg}^{-1}$ ), decreasing towards the estuary mouth (st.J: $87 \pm 12$ $\mathrm{mg} \cdot \mathrm{kg}^{-1}$ ) to fall in the ria seawater to $7 \mathrm{mg} \cdot \mathrm{kg}^{-1}$ although high concentrations were observed in semi-closed inlets such as the harbour of Corme (st.M: $31 \pm 8 \mathrm{mg} \cdot \mathrm{kg}^{-1}$ ). As regards temporal variation, maximum levels of P-As in the river occurred at the beginning of summer (145-169 $\mathrm{mg} \cdot \mathrm{kg}^{-1}$ in June-July) and at the end of autumn (November-December, around $200 \mathrm{mg} \cdot \mathrm{kg}^{-1}$ ), probably as results of the arrival of stormy weather and the first storms. These fluvial P-As concentrations correspond to daily river flows of up to $24 \mathrm{~m}^{3} \cdot \mathrm{s}^{-1}$; however, from December 2005 to March 2006 five flow-rate spikes occurred (four in the range of $50-60 \mathrm{~m}^{3} \cdot \mathrm{s}^{-1}$ and one of $80 \mathrm{~m}^{3} \cdot \mathrm{s}^{-}$ $\left.{ }^{1}\right)$ and besides, four cases of flow higher than $100 \mathrm{~m}^{3} \cdot \mathrm{s}^{-1}$ since 1971; in these events, P-As concentrations in the Anllóns River may be different as compared to those observed.

When the SPM content of water is considered and the particulate arsenic concentration expressed in $\mu \mathrm{g} \cdot \mathrm{L}^{-1}$, the particulate arsenic trend in the Anllóns River is seen to increase at the same time as the river flow (Fig.4). Also, the P-As increased 1.7 \pm 0.5 times after the Anllóns River crossed the Corcoesto zone.

From the SPM in $\mu \mathrm{g} \cdot \mathrm{L}^{-1}$ the relationship between DI-As and P-As can be calculated using the dimensionless partition coefficient $K_{D}$, that is defined as the ratio of dissolved $(w / v)$ to particulate 
$(\mathrm{w} / \mathrm{v})$ arsenic concentration; $K_{D}$ increased when the flows drop from winter to summer, $0.3 \pm 0.1$ in January, $1.6 \pm 0.5$ in March and $24 \pm 11$ in August, (Fig.4). The estuary also showed this $K_{D}$ trend but to a less marked extent: $0.9 \pm 0.7,3.0 \pm 0.2$ and $5.5 \pm 0.3$, respectively, in the aforementioned three months. In the ria the dissolved arsenic phase always prevailed. DI-As was one or two orders of magnitude higher than P-As. Dissolved plus particulate arsenic concentrations in the water column of this Galician coastal system does not exceed $5 \mu \mathrm{g} \cdot \mathrm{L}^{-1}$ and it was not lower than $1 \mu \mathrm{g} \cdot \mathrm{L}^{-1}$.

\subsection{Arsenic in surface sediments}

The arsenic concentrations in the fine fraction of the surface sediments in the Anllóns-Laxe coastal system are shown in Table 4. Arsenic levels varied from 13 to $47 \mathrm{mg} \cdot \mathrm{kg}^{-1}$ in the river and from 3 to $19 \mathrm{mg} \cdot \mathrm{kg}^{-1}$ in the ria sediments if the fishing ports of Corme $\left(86 \mathrm{mgAs} \cdot \mathrm{kg}^{-1}\right)$ and Laxe (198 $\mathrm{mgAs} \cdot \mathrm{kg}^{-1}$ ) are not considered. Another zone with sediments enriched in arsenic was the estuary which varied from 15 to $308 \mathrm{mg} \cdot \mathrm{kg}^{-1}$.

The arsenic in sediments in the Anllóns river-estuary (Table 4) increased slowly (17-23 mg $\cdot \mathrm{kg}^{-}$ $\left.{ }^{1}\right)$ in the upper river section as far as the Corcoesto area where it increased to $47 \mathrm{mg} \cdot \mathrm{kg}^{-1}$; a second significant rise occurred in the estuarine area (up to $308 \mathrm{mg} \cdot \mathrm{kg}^{-1}$ ). The highest concentrations of the entire coastal system were observed in the middle estuary where salinity changed from 0 to 10 in winter and from 0 to 25 in summer. In this fluvial zone alluvial deposits accumulate (IGME 1981b) and the fine fraction of sediment (12-41\%) is the highest of the whole coastal system. The arsenic decreased towards the estuary end $\left(26 \mathrm{mg} \cdot \mathrm{kg}^{-1}\right)$ and likewise in direction of the mouth of the Ria $\left(10 \mathrm{mg} \cdot \mathrm{kg}^{-1}\right)$. Iron concentrations are the highest in the estuarine mixing zone, i.e. $47 \pm 3 \mathrm{~g} \cdot \mathrm{kg}^{-1}$ in contrast to $17 \pm 9 \mathrm{~g} \cdot \mathrm{kg}^{-1}$ in the remainder of sediments of other areas.

The evaluation of the arsenic enrichment in the surface sediments requires the accurate knowledge of the background values. These can be calculated by means of a geochemical normalization using the fine fraction of sediment and a reference element (Luoma et al., 1990). For this study, aluminium was chosen to normalize arsenic data because it is a major constituent of the fine grained aluminosilicates which the bulk of arsenic is associated, it is highly refractory to estuarine processes and its concentration is generally not influenced by anthropogenic sources (Prego et al., 2008). Therefore, arsenic background concentration ([As] $]_{\mathrm{BV}}$ in $\mathrm{mg} \cdot \mathrm{kg}^{-1}$ ) in the Anllóns-Laxe system is defined (Fig.5) as a function of aluminium $\left(\mathrm{g} \cdot \mathrm{kg}^{-1}\right)$ following the linear regression line:

$$
[A s]_{\mathrm{BV}}=0.90 \cdot[\mathrm{Al}]-6.3 \quad(r=0.88 ; n=20 ; p<0.001)
$$

The theoretical natural concentration of arsenic can be established in each sample from its aluminium concentration (Table 4) and, consequently, it is possible to ascertain the state of arsenic contamination in sediments using the enrichment factor (EF). This is defined for the sediment sample $\mathrm{N}$ with the arsenic concentration $[\mathrm{As}]_{\mathrm{N}}$ as the number of times that the natural reference concentration, $[A s]_{\mathrm{BV}}$, is exceeded, according to the equation:

$$
\mathrm{EF}_{\mathrm{N}}=[\mathrm{As}]_{\mathrm{N}} /[\mathrm{As}]_{\mathrm{BV}}
$$

Sediment enrichment factors for arsenic, $\mathrm{EF}_{\mathrm{As}}$, in the Anllóns River, its estuary and the Laxe Ria are shown in Table 4. Thus, sediment can be classified (Hakanson, 1980) as contaminated, i.e. $3<\mathrm{EF}_{\mathrm{As}}<6$, just after the old mining area of Corcoesto and at the start of estuarine zone and as high contaminated, i.e. $\mathrm{EF}_{\mathrm{AS}}>6$, in the of Corme and Laxe harbors.

\subsection{Arsenic fluvial fluxes}

Theoretically, fluxes ( $\Phi$ in mass per time unit) are derived from the continuous measurements of both water discharges $\left(Q\right.$ in $\mathrm{m}^{3} \cdot \mathrm{s}^{-1}$ ) and concentrations ( $C$ in mass per volume, $\mu \mathrm{g} \cdot \mathrm{L}^{-1}$ ) between time $t_{1}$ and $t_{2}$ (Meybeck et al., 1992), according to:

$$
\Phi=\int_{\mathrm{t} 2}^{\mathrm{t} 1} \mathrm{C}(\mathrm{t}) \cdot \mathrm{Q}(\mathrm{t}) \delta \mathrm{t}
$$


To calculate the flux is necessary relied on discrete measurements at fixed sampling periods. So, an appropriate approach to the quantification of the annual arsenic contribution from the Anllóns River is to multiply the daily flow by its arsenic content:

$$
F=\sum_{i=365}^{i=1} Q_{i} \cdot[A s]_{i}
$$

where $F\left(\mathrm{~kg} \cdot \mathrm{a}^{-1}\right)$ is the annual flux, $\mathrm{Q}$ is the daily river flow $\left(\mathrm{m}^{3} \cdot \mathrm{s}^{-1}\right)$, and [As] is the daily concentration of inorganic dissolved or total suspended particulate arsenic $\left(\mu \mathrm{g} \cdot \mathrm{L}^{-1}\right)$.

The daily river flow is known, it was daily averaged (Fig.2) from the limnigraph record in the gauging station of Anllóns (st.F in Fig.1). On the other hand, the daily concentration of arsenic may be calculated (Webb et al., 1995) from the daily flow data using arsenic-flow exponential equations (Meybeck et al., 1992; Thomas and Meybeck, 1992). These equations were obtained (Fig.4) from the monthly data of DI-As and P-As (Tables 2 and 3 ) and the corresponding river flow (Table 1); so, arsenic concentrations in the Anllóns River may be estimated by means of the exponential equations:

$$
\begin{array}{lll}
{[D I-A s]=7.09 \cdot Q^{-0.69}} & (r=0.94, p<0.001) & (5) \\
{[P-A s]=0.059 \cdot Q^{0.92}} & (r=0.95, p<0.001) & (6)
\end{array}
$$

where [DI-As] and [P-As] are, respectively, the dissolved inorganic and particulate arsenic concentrations $\left(\mu \mathrm{g} \cdot \mathrm{L}^{-1}\right)$ in the gauging station and $Q$ is the river discharge $\left(\mathrm{m}^{3} \cdot \mathrm{s}^{-1}\right)$.

During the year of study, applying the equations (4) and (5), the fluvial contributions to the estuary were 13.26 of DI-As; with regards to P-As the flux from equations (4) and (6) was 9.35 $\mathrm{mg} \cdot \mathrm{s}^{-1}$ but this flux is approximate in default because equation (6) was calculated using river flows up to $24 \mathrm{~m}^{3} \cdot \mathrm{s}^{-1}$, lower than the flow rate spikes in the Anllóns River. In comparison, when the daily water discharges of 30 years are considered (1971-2001), the annual exportations of DI-As can be estimated to be $13.7 \pm 1.0 \mathrm{mg} \cdot \mathrm{s}^{-1}$ and the P-As higher than $12.4 \mathrm{mg} \cdot \mathrm{s}^{-1}$ (the annual average flow of these 30 years was $\left.11.3 \pm 2.5 \mathrm{~m}^{3} \cdot \mathrm{s}^{-1}\right)$.

\subsection{Mixing curves of arsenic in the estuary}

The theoretical dilution lines and mixing curves were considered to determine the pattern of DI-As in the Anllóns estuary assuming steady-state conditions during samplings (Mantoura and Morris, 1983). The typical trends observed in the Anllóns estuary of concentration versus salinity (c-S) relationships are illustrated in Fig.6. The conservative dilution is defined by the straight line linking the freshwater $\left(S=S_{R W}=0 ; c=C_{R W}\right)$ and marine $\left(S=S_{S W} ; c=C_{S W}\right)$ end-members of estuary. During spring and summer inorganic dissolved arsenic in the freshwater end (1.3-3.8 $\left.\mu \mathrm{g} \cdot \mathrm{L}^{-1}\right)$ was higher than that measured in the marine end, whilst the opposite $\left(0.5-1.4 \mu \mathrm{g} \cdot \mathrm{L}^{-1}\right.$ in river) was observed in autumn and winter as it is shown in Fig.6. It can be seen that DI-As showed two patterns of behaviour, one with positive and another negative; in both cases the arsenic pattern was not conservative. During the wet season (except for December) an addition of DI-As occurred in the Anllóns estuary whilst its depletion occurred during the dry season (except for August).

Similar procedure applying mixing curves can be applied to P-As (Fig.6). Its trend in the mixing of river and sea water was the opposite of addition and removal shown by DI-As. Although three months were only considered, the trend suggests a removal in the wet season and addition in the dry season. In all cases the fluvial-end contained more suspended arsenic than the marine-end.

The fractional gain or loss of arsenic in the estuary $(G)$ can be calculated from the theoretical dilution line (Mantoura and Morris, 1983) or by areas quotient applying the expression:

$$
G=\frac{\int_{S_{R W}}^{S_{S W}} c(S) \cdot d S}{\frac{\left(c_{R W}+c_{S W}\right)}{2} \cdot\left(S_{S W}-S_{R W}\right)}
$$


where dividend is the integral that corresponds to the area under the curve of real c-S mixing $\left(\mathrm{S}_{\mathrm{RW}}=0\right)$ and the divisor is the area resulting from the conservative behaviour in the estuary.

Dissolved inorganic arsenic transported by the river water during the wet season (autumn and winter) tends to increase in concentration to $28 \pm 10 \%$ in the estuary and during the dry season on the contrary (spring and summer), dissolved inorganic arsenic tends to decrease in concentration to $17 \pm 4 \%$ when it moves from the river to the ria. On the other hand, as regards particulate arsenic this decreased by $35 \%$ in January, and increased by $6 \%$ in March and $750 \%$ in August.

\section{DISCUSSION}

\subsection{The fluvial reservoir}

The spatial distribution of dissolved and particulate arsenic along the course of the Anllóns River is highly dependent on the different bedrock lithology. In general, arsenic concentration in rocks ranges from 0.5 to $2.5 \mathrm{mg} \cdot \mathrm{kg}^{-1}$ (Kabata-Pendias and Pendias, 1984). The average content of this element in uncontaminated soil rarely exceeds $10 \mathrm{mg} \cdot \mathrm{kg}^{-1}$ (Krysiak and Karczewska, 2007), which is the case of the upper Anllóns basin where arsenic concentrations of $2-5 \mathrm{mg} \cdot \mathrm{kg}^{-1}$ were reported (Guitián-Ojea, 1986), as is usual on soils developed on igneous and metamorphic rocks (Smedley and Kinniburgh, 2002). In the upstream zone DI-As concentrations were lower than 2 $\mu \mathrm{g} \cdot \mathrm{L}^{-1}$ and the Anllóns showed background levels of the same order as other rivers $\left(0.1-1.7 \mu \mathrm{g} \cdot \mathrm{L}^{-1}\right.$; Chester, 1993). Where the river crosses the Corcoesto area there is mineralized zones with semimassive arsenopyrite reaching $100 \mathrm{~g} \cdot \mathrm{kg}^{-1}$ of As, and in the superficial soil horizons of this mineralized areas up to $4 \mathrm{~g} \cdot \mathrm{kg}^{-1}$ have been detected (Devesa-Rey et al., 2008). This natural geological zone of arsenic enrichment associated with gold ores, as has been observed in other rivers near gold mines (Serfor-Armah et al. 2006; Moreno et al., 2007), releases arsenic from the river bed sediments (Rubinos et al., 2010) to double the levels of DI-As in the Anllóns River water so that they reach the lower limit $\left(4.5 \mu \mathrm{g} \cdot \mathrm{L}^{-1}\right)$ of polluted European Rivers (Plant et al., 2003). Also, in spite of this increase of arsenic, all the dissolved concentrations measured in Anllóns River are lower than the permissible limit for drinking water, $10 \mu \mathrm{g} \cdot \mathrm{L}^{-1}$ (Council Directive 98/83/EC; USEPA, 1975; WHO, 2001).

In the Anllóns upper course, where sediments are uncontaminated, P-As concentrations are similar to those of other fluvial systems (Helios-Rybicka et al., 2005; Masson et al., 2007). Further downstream in the ancient gold-mining area of Corcoesto, P-As concentrations in SPM were up to three times higher than in the upper course (Table 3 ) emphasizing the influence of the local geological context. Fine sediments (grain size $<63 \mu \mathrm{m}$ ) just downstream the Corcoesto area showed As contamination (Table 4) up to $47 \mathrm{mg} \cdot \mathrm{kg}^{-1}$ of As being found. This contamination is more important even if the total fraction $\left(<2 \mathrm{~mm}\right.$ ) of sediment is considered, i.e. $101-264 \mathrm{mg} \cdot \mathrm{kg}^{-1}$ of As (Rubinos et al., 2003; Devesa-Rey et al., 2008). It should be a consequence of quick flow peak of Anllóns that may transport larger size particles of sediment from the mining zone.

The arsenic enrichment of freshwater continues downstream as far as the gauging station of Anllóns, the freshwater limit of estuary. At this boundary, temperature and $\mathrm{pH}$ temporal changes in the well oxygenated river water were low and arsenic follows natural patterns, i.e. is dependent on river flow (Fig.4): DI-As shows the typical dilution curve with an exponential decrease in concentration with discharge (Meybeck et al., 1992), whilst the opposite trend was associated with P-As, i.e. it exhibited an exponential increase in concentration, which usually occurs with elements bound to particulate matter (Thomas and Meybeck, 1992). The aforementioned patterns of behaviour of arsenic in waters were also observed in another temperate low-contaminated river, the Adour by Point et al. (2007). The relationship between dissolved and particulate arsenic was highly dependent on flow but during annual average flow it was 1:1, as described in one third of 49 groundwater sources in USA (Chen et al., 1999).

Changes in the fluvial or groundwater concentrations of DI-As may be influenced by variations in the $\mathrm{pH}$ and temperature. Significant $\mathrm{As}(\mathrm{V})$ desorption occurs at $\mathrm{pH} 8$ and higher (Lumsdom et 
al., 2001) whilst it is desorbed from water at low pH, being strongly adsorbed by hydrous ferric oxide (Plant et al., 2003). This is not the case in the Anllóns River where the $\mathrm{pH}$ range remains slightly basic. On the other hand, in the Anllóns River a positive correlation between water temperature $\left(\mathrm{t}\right.$ in $\left.{ }^{\circ} \mathrm{C}\right)$ and $\mathrm{DI}-\mathrm{As}\left(\mu \mathrm{g} \cdot \mathrm{L}^{-1}\right)$ was detected:

$$
[D I-A s]=0.16 \cdot t-0.90 \quad(r=0.81 ; n=12, p<0.01)
$$

Similar evidence of seasonal fluctuations of DI-As concentrations can be found in Waikaro River (New Zealand). McLaren and Kim (1995) suggested that the dominant effect of temperature is likely due to desorption of As from the river sediments and a temperature-controlled microbial reduction derived from microbiological activity in summer. Hence, the positive correlation of DIAs with temperature in the Anllóns River may reflect that pattern.

The impact of the Corsoesto arsenopite zone on the content of dissolved and particulate arsenic in the Anllóns River means that the fluvial discharge at the river end-member of the estuary doubles its transportation of arsenic to $430 \pm 30 \mathrm{~kg} \cdot \mathrm{a}^{-1}$ of inorganic dissolved arsenic and more than $390 \mathrm{~kg} \cdot \mathrm{a}^{-1}$ of particulate arsenic if there is quick flow peak surpassing $24 \mathrm{~m}^{3} \cdot \mathrm{s}^{-1}$. Very low concentrations of dissolved organic arsenic have been measured in contaminated waters from many disused mines $\left(<0.2 \mu \mathrm{g} \cdot \mathrm{L}^{-1}\right.$; Hunt and Howard, 1994) whereas in groundwater it is usually small or negligible (Plant et al., 2003). This occurs equally to fluvial waters (Froelich et al., 1985) and also to the Anllóns River. Therefore, the DO-As contribution to the arsenic transport may represent less than $30 \mathrm{~kg} \cdot \mathrm{a}^{-1}$. Taking this into account, the Anllóns River supplies at least 850 $\mathrm{kg}$ of arsenic to the estuary annually.

The flux of DI-As in the Anllóns River is small compared with that of other temperate rivers: it is one order of magnitude lower than the flux calculated for the Thames (Millward et al., 1997) and Adour (Point et al., 2007) whilst it is two orders of magnitude lower than contributions of the Seine (Michel et al., 1999), Loire (Seyler and Martin, 1990), Garonne (Michel et al., 1998), Rhone (Guieu et al., 1991) and Humber (Kitts et al., 1994). Although, to draw a meaningful comparison, this output must by normalized with respect to the area of the river basin; if it is done the DI-As of the Anllóns $\left(0.83 \mathrm{~kg} \cdot \mathrm{s}^{-1} \cdot \mathrm{km}^{-2}\right)$ is higher than that of the noted rivers $\left(0.44-0.64 \mathrm{~kg} \cdot \mathrm{s}^{-1} \cdot \mathrm{km}^{-2}\right)$.

\subsection{The Estuarine reservoir}

Estuaries can be divided into those in which the principal arsenic input is of marine origin (Waslenchuk and Windom, 1978; Howard et al., 1984; Froelich et al., 1985) and those in which the river is the major arsenic source (Andreae et al., 1983; Knox et al., 1984; Millward and Marsh, 1986). In this respect the Anllóns estuary shows an ambivalent behaviour. On the one hand, during the wet season the concentration of river dissolved inorganic arsenic is lower than its content in seawater; on the other hand, the opposite occurs during the dry season. According to the flow-concentration curve (Fig.4) the dilution effect on DI-As in the rainy season decreases its concentration to below the marine range (St.L: $1.4 \pm 0.5 \mu \mathrm{g} \cdot \mathrm{L}^{-1}$ ); on the contrary, during the dry season, when the river flow is low, the DI-As increases above that of the seawater. The contribution due to the arsenopyrite, which doubles the fluvial concentration of DI-As, is relevant.

When the arsenic in the fluvial water enters the Anllóns estuary and mixes with the seawater the dilution lines of dissolved and particulate arsenic show a non-conservative pattern (Fig.6). Whether or not arsenic behaves conservatively during estuarine mixing depends on the nature of the studied system. Dissolved inorganic arsenic has been reported to be conservative in the estuary of the Humber (Kitts et al., 1994), Rhone (Elbaz-Poulichet et al., 1996), Thames (Millward et al., 1997), and in the south-eastern U.S.A. estuaries (Waslenchuk and Windom, 1978; Froelich et al., 1985; Michel et al., 1999). Whilst a non-conservative behaviour, characterized by either removal or mobilization, has been found in the estuary of Krka (Seyler and Martin, 1990), Seine (Michel et al., 1999), Schelde (DeGieter et al., 2005), Zhujiang (Yao et al., 2006) and several U.K. estuaries (Langston, 1983). However, in the case of the estuary of the Anllóns both, loss and gain, were observed. 
In the ambivalent pattern of DI-As during the estuarine mixing, the P-As factor must be considered. The dilution curve of P-As in January (Fig.6) suggests that if the DI-As is low $\left(0.72 \mu \mathrm{g} \cdot \mathrm{L}^{-}\right.$ $\left.{ }^{1}\right)$ but the P-As high $\left(1.85 \mu \mathrm{g} \cdot \mathrm{L}^{-1}\right)$ then, an arsenic flux from SPM to dissolved is possible; whilst in August the opposite occurs, particulate $\left(0.10 \mu \mathrm{g} \cdot \mathrm{L}^{-1}\right.$ at fluvial end-member) is enriched in arsenic from dissolved $\left(3.82 \mu \mathrm{g} \cdot \mathrm{L}^{-1}\right)$. Arsenic in the sediment can also play a role in the arsenic exchange. Non-conservative behaviour in estuaries due to processes such as diffusion from sediment pore waters or co-precipitation with iron oxides has been observed (Andreae et al., 1983; Andreae and Andreae, 1989). Estuaries polluted with anthropogenic sources of arsenic generally display high As-levels with input maxima somewhere within the estuary (Froelich et al., 1985); such a behaviour occurs in the mid-estuary of Tamar which has 3.7-5.3 $\mu \mathrm{g} \cdot \mathrm{L}^{-1}$ of arsenic attributed to a release from arsenic-rich estuarine sediments (Knox et al., 1984).

The sediment of the Anllóns estuary is rich in arsenic (120-310 $\mathrm{mg} \cdot \mathrm{kg}^{-1}$ in fine fraction, Fig.5; 50-72 $\mathrm{mg} \cdot \mathrm{kg}^{-1}$ in total fraction, Devesa-Rey et al., 2008), 2.8 times higher than those of the river and of the ria. The main arsenic enrichment in the sedimentary reservoir of estuary occurs between stations 7 to 11 , happening in parallel with the increase in iron concentrations (Table 4). Thus, in the estuarine zone, arsenic shows the following correlation with iron:

$$
\left[\text { As }\left(\mathrm{mg} \cdot \mathrm{kg}^{-1}\right)\right]=1.00 \cdot\left[\mathrm{Fe}\left(\mathrm{g} \cdot \mathrm{kg}^{-1}\right)\right]+14 \quad(\mathrm{r}=0.91 ; \mathrm{n}=11, \mathrm{p}<0.01)
$$

Several authors (Sánchez-Rodas et al., 2005 and references cited therein) have already pointed out the arsenic adsorption and co-precipitation with ferric oxy-hydroxides associated with salinity and $\mathrm{pH}$ changes during the estuarine mixing. Both changes in the Anllóns estuary appear between the aforementioned stations, salinity rises from 0.1 to 10 during the wet season or 0.125 during the dry season and $\mathrm{pH}$ increases from 7.2 to 8.1. So, $\mathrm{pH}$ and salinity plays an important role in the removal of arsenic from the Anllóns waters, like in other estuarine boundaries (Maher and Butler, 1988). In the removal process, the weaker adsorption of $\mathrm{As}(\mathrm{V})$ at high $\mathrm{pH}$, when $\mathrm{As}(\mathrm{III})$ may be more strongly bound in the region $\mathrm{pH} 8-9$, has important environmental involvements (Plant et al., 2003). In this way, research is necessary in the Anllóns estuary about the arsenic speciation with regard to $\mathrm{pH}$ and iron and manganese oxides.

According to the sediment quality guidelines (Long et al., 1995), the arsenic concentrations in the estuary surpass considerably the ERM value $\left(70 \mathrm{mg} \cdot \mathrm{kg}^{-1}\right)$ and therefore could pose an environmental risk. DI-As could be exported from this contaminated strip (Table 4) during the wet season. During the dry season P-As increases (Fig.6) and the DO-As concentration reaches $9 \%$ in May. Following this, the biological activity intensify in the coastal system (Varela et al., 2005) and fluvial SPM is very low (Fig.4 and 6); thus, it may be hypothesised that processes of arsenic coprecipitation with iron oxides can be less relevant than phytoplankton uptake and settling in the estuary.

Finally, when the fluvial arsenic reaches the ria its concentration varies due to the estuarine processes. So, the estuarine contribution of DI-As to the ria may increase one third during the wet season and decrease one fifth during the dry season. According to this assumption, the estuarine flux to the ria is estimated to be $470 \mathrm{~kg} \cdot a^{-1}, \approx 10 \%$ higher than the fluvial flux. In the case of P-As more data are necessary to quantify its changes across the estuary.

\subsection{The Ria reservoir}

Concentrations of DI-As in the Ria of Laxe ranged from $0.56 \pm 0.10 \mu \mathrm{g} \cdot \mathrm{L}^{-1}$ in December to $2.32 \pm 0.24 \mu \mathrm{g} \cdot \mathrm{L}^{-1}$ in May and they were similar to those of other parts of the coast of Spain (0.5-3.7 $\mu \mathrm{g} \cdot \mathrm{L}^{-1}$; Plant et al., 2003) or in the oceans ( $\approx 1.6 \mu \mathrm{g} \cdot \mathrm{L}^{-1}$; Millero and Sohn, 1992; Donat and Bruland, 1995). This indicates that the estuarine output to the ria during the dry season is diluted to the levels found in the sea and this is only possible if the seawater renewal of ria is important. The hypsographic characteristic of this ria, an open-sea bay, and its circulation reinforced by river outflow and upwelling events (Varela et al., 2005) favours the arsenic exportation to the ocean.

The estuarine arsenic in the SPM, as occurs with the dissolved, arsenic should be mainly exported offshore from the ria. Enrichment factors do not show sediment contamination, in fact 
quite the opposite in the estuary, except for the port areas (Table 4 and Fig.5). The sediment inside the two fishing ports is heavily contaminated with arsenic. High levels of arsenic were found in several ports of Spain (Casado-Martinez et al., 2006). Inside ria the quays and docks structures of ports can operate as SPM traps from the estuary. Thus, P-As was 2-4 times higher in the port of Corme (st.M, Table 3) than in open ria waters and their sediments are contaminated.

Dissolved organic arsenic in seawaters of the ria was $22 \%$ inorganic in May and only $9 \%$ in March and August, these are analogous levels to there of the in the North Sea $(<29 \%$; Millward et al., 1996). Concentrations of both phases of dissolved arsenic depend on the phytoplankton activity because of its similarity with phosphate cycle (Sanders and Windom, 1980). Thus, dissolved arsenic may oscillate in amount month to month following the frequent changes of phytoplankton and dissolved phosphate levels in the ria during prebloom (in winter), bloom (in spring) and upwelling (in summer) (Varela et al., 2005).

\section{CONCLUSION: River-estuary-ria as a whole}

In general, dissolved and particulate arsenic concentrations found in the Anllóns River were of the same order of there observed in European rivers that are considered low or moderate contaminated. The main difference is due to the local lithology (arsenopyrites) in the middle fluvial basin which produces twice the arsenic levels in the river. It determines the input of dissolved inorganic arsenic to estuary where it shows two particular patterns. One was the ambivalent addition or removal of dissolved inorganic arsenic depending on the whether it is a dry or wet season, i.e. the variation of fluvial flow; another was the marked sediment enrichment in iron and arsenic, which may be a barrier to the particulate and bed load arsenic. In this subject, further research is advisable about the role of flow rate spikes in the river. When the arsenic finally arrives in the ria, the circulation of the seawater dilutes and disperses it. The dissolved arsenic and the particulate in part, are mainly exported to the ocean because the levels of this element in the ria are the normal for NE Atlantic Ocean.

The arsenic load to the ocean is a result of ria characteristics since the fresh- and sea-water mixing only occurs in its innermost zone and there is an easy ria-ocean exchange. In this one directional transport the estuarine processes modified the seasonal arsenic exportation to the ria, but they did not change significantly the outgoing flux of dissolved inorganic arsenic. Thus, in the Anllóns-Laxe system as a whole, the freshwater-saline interface processes do not lead to a decrease in the dissolved fluvial arsenic flux to the ocean.

Acknowledgements. We are grateful to the Captain Jorge Alonso and the crew of R/V Mytilus for the kind cooperation during the sea works; to Dr. M.A.A. Enjo (USC) for the daily Anllóns River inflow data; to A. Labandeira for her technical support; to C. Trujillo, P. Ferro and L. García for their help during the monthly sampling; we specially thank to Prof. Graham Evans (re. Imperial College, UK) for his valuable review to the manuscript and its English language; and two anonymous reviewers for their kind suggestions, which improved our work. This study was supported by the project REN2002-04629-C03 in cooperation with the project CTM2007-62546C03-01/MAR, both financed by the CICYT. This article is a contribution to the Spanish-LOICZ Program. 


\section{REFERENCES}

Aminot A. Dosage de l'oxygène dissous. In: Aminot A, Chaussepied M, editors. Manuel des Analysses Chimiques en Milieu Marin. CNEXO, Brest, 1983, pp. 75-92.

Andreae MO, Byrd JT, Froelich PN. Arsenic, antimony, germanium, and tin in the Tejo estuary, Portugal: modeling a polluted estuary. Environ Sci Technol 1983; 17: 731-737.

Andreae MO, Andreae TW. Dissolved arsenic species in the Schelde estuary and watershed, Belgium. Estuar Coast Shelf Sci 1989; 29:421-433.

Balci A. Recent sediments as a trap for the trace metals in a estuarine and coastal marine environment, Turkey. Fresenius Environ Bull 1999; 8: 65-71.

Casado-Martínez MC, Buceta JL, Belzunce MJ, DelValls TA. Using sediment quality guidelines for dredged material management in commercial ports from Spain. Environ Int 2006; 32: 388-396.

Castro E, Lavilla I, Bendicho C. Photolytic oxidation of As species for determination of total As (including the 'hidden' As fraction) in coastal seawater by hydride generation-atomic fluorescence spectrometry. Talanta 2007; 71: 51-55.

Chen HW, Frey MM, Clifford D, McNeill LS, Edwards M. Arsenic treatment considerations. J Am Water Works Assoc 1999; 91, 74-85.

Chester R. Marine geochemistry. Chapman \& Hall, London, 1993, 698 pp.

Council Directive 98/83/EC. Quality of water intended for human consumption. Official Journal of the European Communities 1998; OJ L 330, 5.12.1998, 32-54.

Crossland CJ, Kremer HH, Lindeboom HJ, Marshall Crossland JI, Le Tissier MDA. Coastal Fluxes in the Anthropocene. The Land-Ocean Interactions in the Coastal Zone Project of the International Geosphere-Biosphere Programme. Spinger-Verlag, Berlin, 2005, 232 pp.

Cullen WR, Reimer KJ. Arsenic speciation in the environment. Chem Rev 1989; 89: 713-764.

De Gieter M, Elskens M, Baeyens W. Fluxes and major transport routes of Arsenic in the Scheldt estuary. Mar Chem 2005; 95: 15-30.

Devesa-Rey R, Paradelo R, Díaz-Fierros F, Barral MT. Fractionation and bioavailability of Arsenic in the bed sediments of the Anllóns River (NW Spain). Water Air Soil Pollut 2008; 195: 189-199.

Donat JR, Bruland KW. Trace Elements in the Oceans. In: Salbu B, Steinnes E. editors. Trace Elements in Natural Waters. CRC Press, Boca Raton FL, 1995, pp. 247-281.

Elbaz-Poulichet F, Garnier J-M, Guan DM, Martin J-M, Thomas AJ. The Conservative Behaviour of Trace Metals ( $\mathrm{Cd}, \mathrm{Cu}, \mathrm{Ni}$ and $\mathrm{Pb}$ ) and $\mathrm{As}$ in the Surface Plume of Stratified Estuaries: Example of the Rhône River (France). Est Coast Shelf Sci 1996; 42: 289-310.

Evans G, Prego R. Rias, estuaries and incised alleys: is a ria an stuary?. Mar Geol 2003; 196: 171-175.

Froelich PN, Kaul IW, Byrd JT, Andreae MO, Roe KK. Arsenic, barium, germanium, tin, dimethylsulphide and nutrient geochemistry in Charlotte Harbour, Florida, a phosphorus enriched estuary. Estuar Coast Shelf Sci 1985; 20: 239-264.

González-Soto E, Villa-Lojo MC, Alonso-Rodríguez E, Neira-Dourado J, Prada Rodríguez D, FernándezFernández E. Speciation of inorganic and organic arsenic in marine sediments from La Coruña estuary. Fresenius J Anal Chem 1996; 355: 713-715.

Guieu C, Martin JM, Thomas AJ, Elbaz-Poulichet F. Atmospheric versus river input of metals to the Gulf of Lions: total concentrations, partitioning and fluxes. Mar Pollut Bull 1991; 22: 176-183.

Guitián-Ojea F. Atlas Geoquímico de Galicia. Xunta de Galicia, Santiago, 1986, 58 pp.

Hakanson L. An ecological risk index for aquatic pollution control. A sedimentological approach. Water Res 1980; 14: 975-1001.

Helios Rybicka E, Adamiec E, Aleksander-Kwaterczak U. Distribution of trace metals in the Odra River system: Water-suspended matter-sediments. Limnologica 2005; 35: 185-198.

Helland A. The importance of selective transport and sedimentation in trend monitoring of metals in sediments. An example from the Glomma estuary, East Norway. Water Air Soil Pollut 2001; 126: 339361.

Howard AG, Arbab-Zavar MH, Apte S. The Behaviour of Dissolved Arsenic in the Estuary of the River Beaulieu. Estuar Coast Shelf Sci 1984; 19: 493-504.

Howard AG, Apte SC, Comber SDW, Morris RJ. Biogeochemical Control of the Summer Distribution and Speciation of Arsenic in the Tamar Estuary. Estuar Coast Self Sci 1988; 27: 427-443.

Hunt LE, Howard AG. Arsenic Speciation and Distribution in the Carnon Estuary Following the Acute Discharge of Contamined Water from a Disused Mine. Mar Pollut Bull 1994; 28-1: 33-38. 
IGME. Mapa geológico de España. Hoja de Carballo (1:50.000), 44. Instituto Geológico y Minero de España, Madrid, 1981a, 36 pp.

IGME. Mapa geológico de España. Hoja de Lage (1:50.000), 43. Instituto Geológico y Minero de España, Madrid, 1981b, $36 \mathrm{pp}$.

Kabata-Pendias A, Pendias H. Trace elements in soils and plants. CRC Press, Boca Raton FL, 1984, 315 pp.

Kitts HJ, Millward GE, Morris AW, Ebdon L. Arsenic biogeochemistry in the Humber estuary, U.K. Est Coast Self Sci 1994; 39: 157-172.

Knox S, Langston WJ, Witfield M, Turner DR, Liddicoat I. Statistical analysis of estuarine profiles: II. Application to arsenic in the Tamar estuary (S.W. England). Estuar Coast Shelf Sci 1984; 18: 623-638.

Krysiak A, Karczewska A. Arsenic extractability in the areas of former arsenic mining and smelting, SW Poland. Sci Total Environ 2007; 379: 190-200.

Labandeira A, Cobelo A, Prego R. La ría de Corme y Laxe: Revisión de su conocimiento. Monografías de Química Oceanográfica 2001; 1: 1-34.

Langston WJ. The behaviour of arsenic in selected United Kingdom estuaries. Can J Fish Aquat Sci 1983; 40: 143-150.

Long ER, Macdonald DD, Smith SL, Calder FD. Incidence of adverse biological effects within ranges of chemical concentrations in marine and estuarine sediments. Environ Manage 1995; 19: 81-97.

Lumsdon DG, Meeussen JCL, Paterson E, Garden LM, Anderson P. Use of solid phase characterisation and chemical modelling for assessing the behaviour of arsenic in contaminated soils. Appl Geochem 2001; 16: 571-581.

Luoma SN, Dagovitz R, Axtaman, E. Temporally intensive study of trace metals in sediments and bivalves from a large river-stuarine system: Suisun Bay/Delta in San Francisco Bay. Sci Total Environ 1990; 685712.

McLaren SJ, Kim ND. Evidence for a seasonal fluctuation of arsenic in New Zealand's longest river and the effect of treatment on concentrations in drinking water. Environ Pollut 1995; 90: 67-73.

Maher W, Butler E. Arsenic in the marine environment. Appl Organomet Chem 1988; 2: 191-214.

Mantoura RFC, Morris, AW. Measurement of chemical distributions and processes. In: Morris AW editor. Practical procedures for estuarine studies. NERS, Plymouth, 1983, pp. 55-100.

Mandal BK, Suzuki KT. Arsenic round the world: a review. Talanta 2002; 58: 201-235.

Masson M, Schäfer J, Blanc G, Pierre A. Seasonal variations and annual fluxes of arsenic in the Garonne, Dordogne and Isle Rivers, France. Sci Total Environ 2007; 373: 196-207.

Matschullat J. Heavy metal contamination of soils: reuse versus disposal. In: Reuther R, editor. Geochemical approaches to environmental engineering of metals. Springer, Berlin, 1996, pp. 81-88.

Matschullat J. Arsenic in the geosphere - a review. Sci Total Environ 2000; 249: 297-312.

Meybeck M, Friedrich G, Thomas R, Chapman D. Rivers. In: Chapman D, editor. Water quality assessment. Chapman and Hall, London, 1992, pp. 239-316.

Michel P, Boutier B, Herbland A, Averty B, Artigas LF, Auger D, Chartier E. Behaviour of arsenic on the continental shelf off Gironde estuary: role of phytoplankton in vertical fluxes during spring bloom conditions. Oceanol Acta 1998; 21: 325-333.

Michel P, Chiffoleau JF, Averty B, Auger D, Chartier E. High resolution profiles for Arsenic in the Seine Estuary. Seasonal variations and net fluxes to the English Channel. Cont Shelf Res 1999; 19: 2041-2061.

Millero FJ, Sohn ML. Chemical Oceanography. CRC Press, Boca Raton FL, 1992, 531 pp.

Millward GE, Marsh JG. Dissolved chemical behaviour in estuaries receiving acid mine waste. In: Lester JN, Perrry R, Sterrit RM, editors. Chemicals in the Environment, Selper, Lisbon, 1986, pp. 470-477.

Millward GE, Glegg GA. Fluxes and retention of trace metals in the Humber estuary. Est Coast Shelf Sci 1997; 44: 97-105.

Millward GE, Kitts HJ, Comber SDW, Ebdon L, Howard AG. Methylated arsenic in the southern North Sea. Estuar Coast Shelf Sci 1996; 43: 1-18.

Millward GE, Kitts HJ, Ebdon L, Allen JI, Morris AW. Arsenic in the Thames Plume, U.K. Mar Environ Res 1997; 44: 51-67.

Mirre JC. Guía dos minerais de Galicia. Ed. Galaxia, Vigo, 1990, 196 pp.

Moreno T, Olroyd A, McDonald I, Gibbons W. Preferential fractionation of trace metals-metalloids into PM10 resuspended from contaminated gold mine tailings at Rodalquilar, Spain. Water Air Soil Pollut 2007; 179: 93-105.

Peña-Vázquez E, Villanueva-Alonso J, Bermejo-Barrera A, Bermejo-Barrera P. Arsenic and antimony distribution in the Ría de Arousa: before and after the Prestige oil tanker sinking. J Environ Monit 2006; 8: 641-648. 
Plant JA, Kinniburgh DG, Smedley PL, Fordyce FM, Klinck BA. Arsenic and Selenium. In: Sherwood-Lollar B, editor. Environmental Geochemistry (Vol. 9 of Treatise on Geochemistry). Elsevier, Amsterdam, 2003, pp. 17-66.

Point D, Bareille G, Amouroux D, Etcheber H, Donard OFX. Reactivity, interactions and transport of trace elements, organic carbon and particulate material in a mountain rage river system (Adour River, France). J Environ Monit 2007; 9: 157-167.

Prego R, Cobelo-García A. Twentieth century overview of heavy metals in the Galician Rias (NW Iberian Peninsula). Environ Pollut 2003; 121: 425-452.

Prego R, Filgueiras AV, Santos-Echeandía J. Temporal and spatial changes of total and labile metal concentration in the surface sediments of the Vigo Ria (NW Iberian Peninsula): Influence of anthropogenic sources. Mar Pollut Bull 2008; 56: 1022-1042.

Rivas MER, Enjo MAA, Viqueira FD-F. Water balance and observed flows in the Anllóns River basin (NW Spain). IAHS-AISH Publication, 2007; 300: 224-231.

Rubinos D, Barral MT, Ruiz B, Ruiz M, Rial ME, Alvarez M. Phosphate and arsenate retention in sediments of the Anllons River (Northwest Spain). Water Sci Technol 2003; 48: 159-166.

Rubinos D, Iglesias L, Devesa-Rey R, Díaz-Fierros F, Barral MT. Arsenic release from river sediments in a gold-mining area (Anllóns River basin, Spain): Effect of time, $\mathrm{pH}$ and phosphorous concentration. Eur J Mineral 2010; 22: 665-678.

Rubio B, Nombela MA, Vilas F. Geochemistry of Major and Trace Elements in Sediments of the Ria de Vigo (NW Spain): an Assessment of Metal Pollution. Mar Pollut Bull 2000; 40: 968-980.

Sánchez-Rodas D, Gómez-Ariza JL, Giráldez I, Velasco A, Morales E. Arsenic speciation in river and estuarine waters from southwest Spain. Sci Total Environ 2005; 345: 207-217.

Sanders JG. Arsenic cycling in marine systems. Mar Environ Res 1980; 2: 257-266.

Sanders JG, Windom HL. The uptake and reduction of arsenic species by marine algae. Estuar Coast Mar Sci 1980; 10: 555-567.

Serfor-Armah Y, Nyarko BJB, Adotey DK, Dampare SB, Adomako D. Levels of arsenic and antimony in water and sediment from Prestea, a gold minino town in Ghana and its environments. Water Air Soil Pollut 2006; 175: 181-192.

Seyler P, Martin JM. Distribution of arsenite and total dissolved Arsenic in major French estuaries: dependence on biogeochemical processes and antropogenic inputs. Mar Chem 1990; 29: 277-294.

Sherrell RM, Ross JM. Temporal variability of trace metals in New Jersey Pinelands streams: Relationships to discharge and pH. Geochim Cosmochim Acta 1999; 63: 3321-3336.

Smedley PL, Kinniburgh DG. A review of the source, behaviour and distribution of arsenic in natural waters. Appl Geochem 2002; 17: 517-568.

Thomas R, Meybeck M. The use of particulate material. In: Chapman D, editor. Water quality assessment. Chapman and Hall, London, 1992, pp. 121-170.

USEPA. Preliminary assessment of suspected carcinogens in drinking water. Report to Congress. EPA number 560475003.; 1975.

USEPA. Method 3052. Microwave assisted acid digestion of siliceous and organically based matrices; 1996.

Varela M, Prego R, Pazos Y, Moroño A. Influence of upwelling and river runoff interaction on phytoplankton assenblages in a Middle Galician Ria and comparison with northern and southern rias (NW Iberian Penisula). Estuar Coast Shelf Sci 2005; 64: 721-737.

Waslenchuk DG, Wisdom HL. Factors controlling estuarine chemistry of arsenic. Estuar Coast Mar Sci 1978; 7: 455-464.

WHO. Guidelines for Drinking-Water Quality: Arsenic in Drinking Water. Fact Sheet 210. World Health Organization, Geneva, 2001.

Webb BW, Phillips JM, Walling DE, Littlewood IG, Watts CD, Leeks GJL. Load estimation methodologies for British rivers and their relevance to the LOIS RACS (R) programme. Sci Total Environ 1995; 194/195: 379-389.

Yao Q-Z, Zang J, Qin XG, Xiong H, Dong L-X. The behavior of Selenium and Arsenic in the Zhujiang (Pearl River) Estuary, South China Sea. Estuar Coast Shelf Sci 2006; 67: 170-180. 


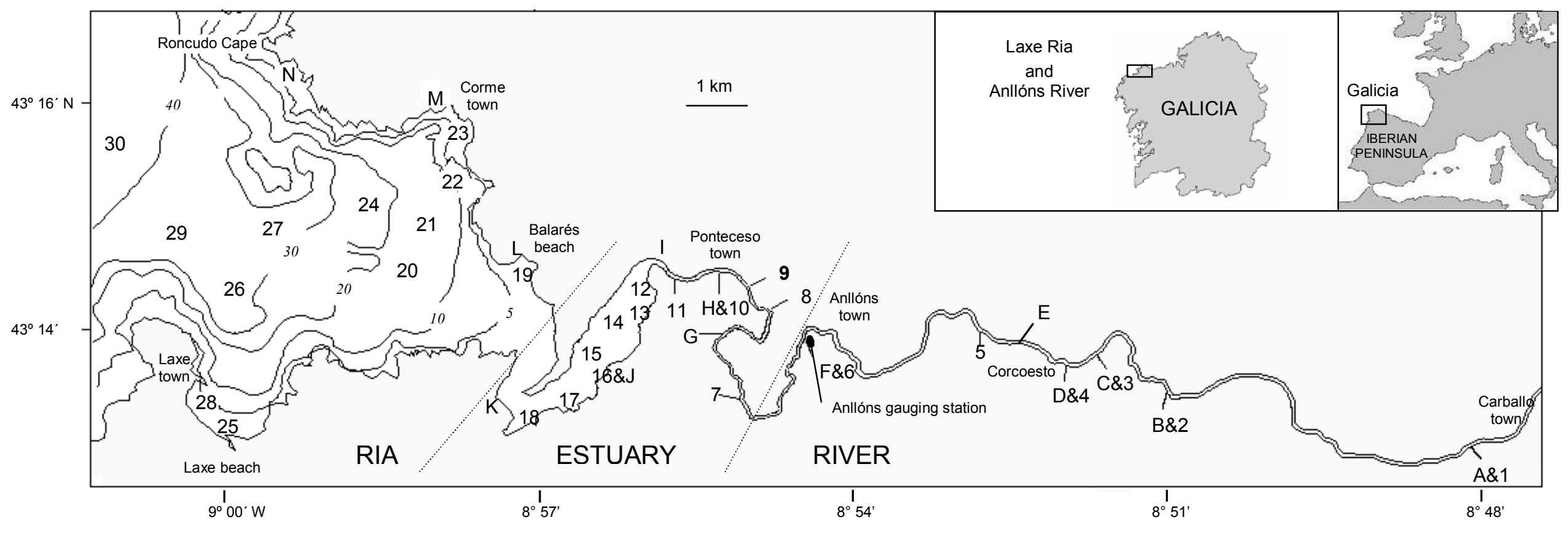

Figure 1. Map of coastal system comprising the Anllóns River, its estuary and the Ria of Laxe (bathymetry in meters). The sampling stations of water are indicated with letters (A-N) and the superficial sediment with numbers (1-30). 


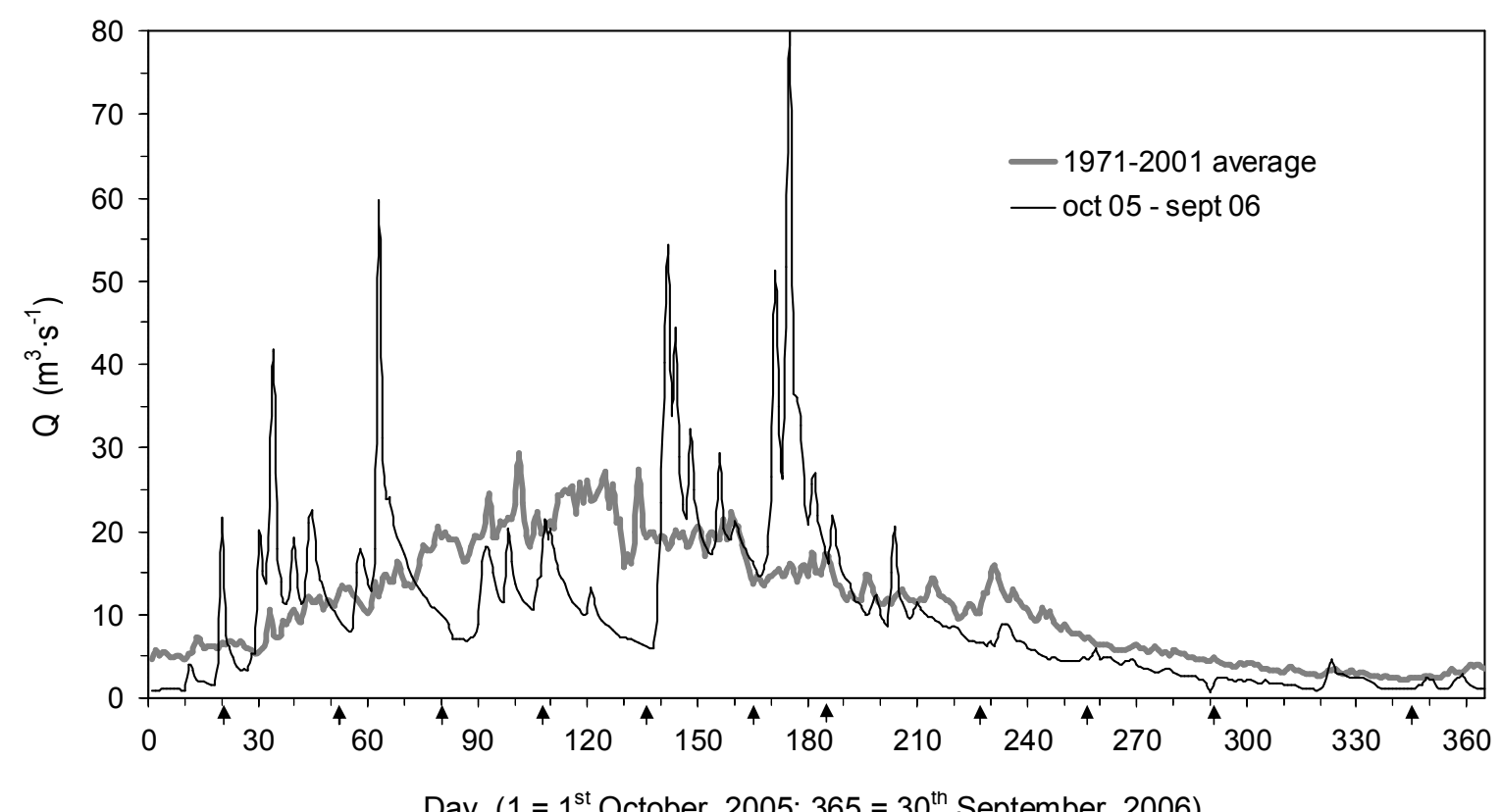

Day $\left(1=1^{\text {st }}\right.$ October, $2005 ; 365=30^{\text {th }}$ September, 2006)

Figure 2. The daily freshwater discharge of the Anllóns River during the research period from October 2005 to September 2006 . The daily average flow for 30 years is also shown as a reference. Arrows indicate the dates of water samplings. 
$\begin{array}{llllllllll}\text { St. K J } & \text { I } & \text { H } & \text { G } & \text { F } & \text { E D C } & \text { B } & \text { A }\end{array}$

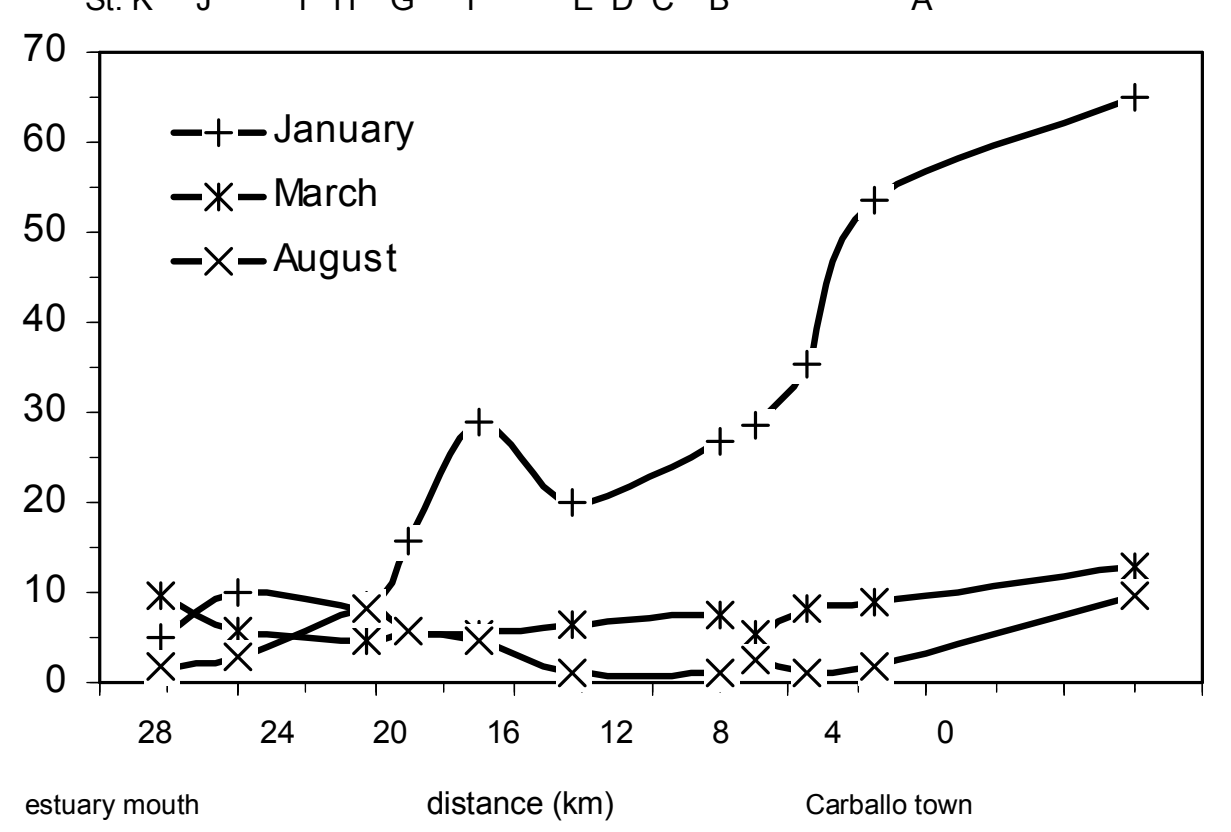

Figure 3. Suspended particulate matter (SPM) concentrations in the waters of Anllóns from the river source to the estuary mouth. Three different conditions of fluvial discharge were selected: January $\left(24 \mathrm{~m}^{3} \cdot \mathrm{s}^{-1}\right)$, March $\left(12 \mathrm{~m}^{3} \cdot \mathrm{s}^{-1}\right)$ and August $\left(2 \mathrm{~m}^{3} \cdot \mathrm{s}^{-1}\right)$. 

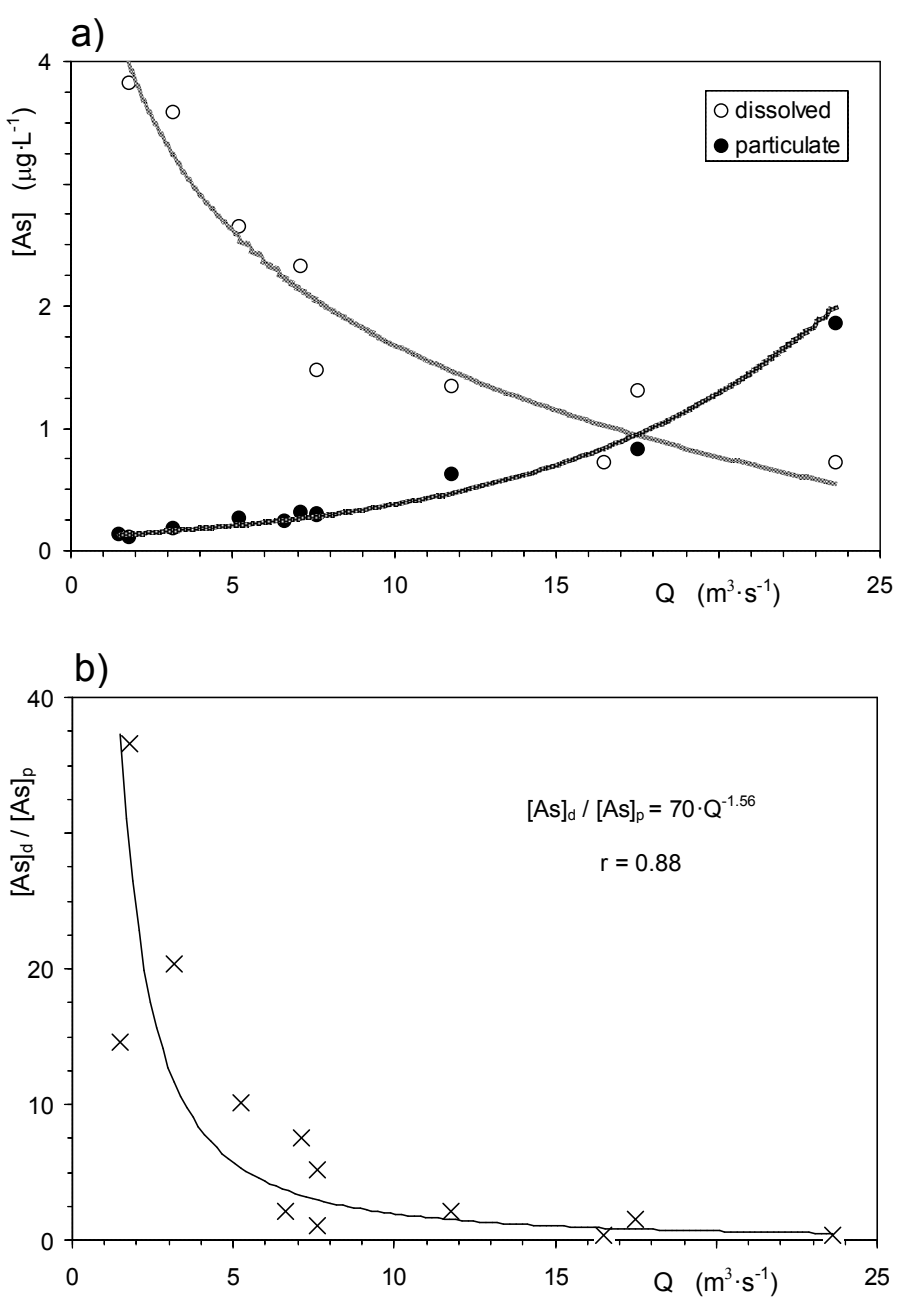

Figure 4. (a) The behaviour of dissolved inorganic arsenic and particulate arsenic concentrations and (b) the dissolved-particulate relationship, versus water discharge at the Anllóns gauging station. 


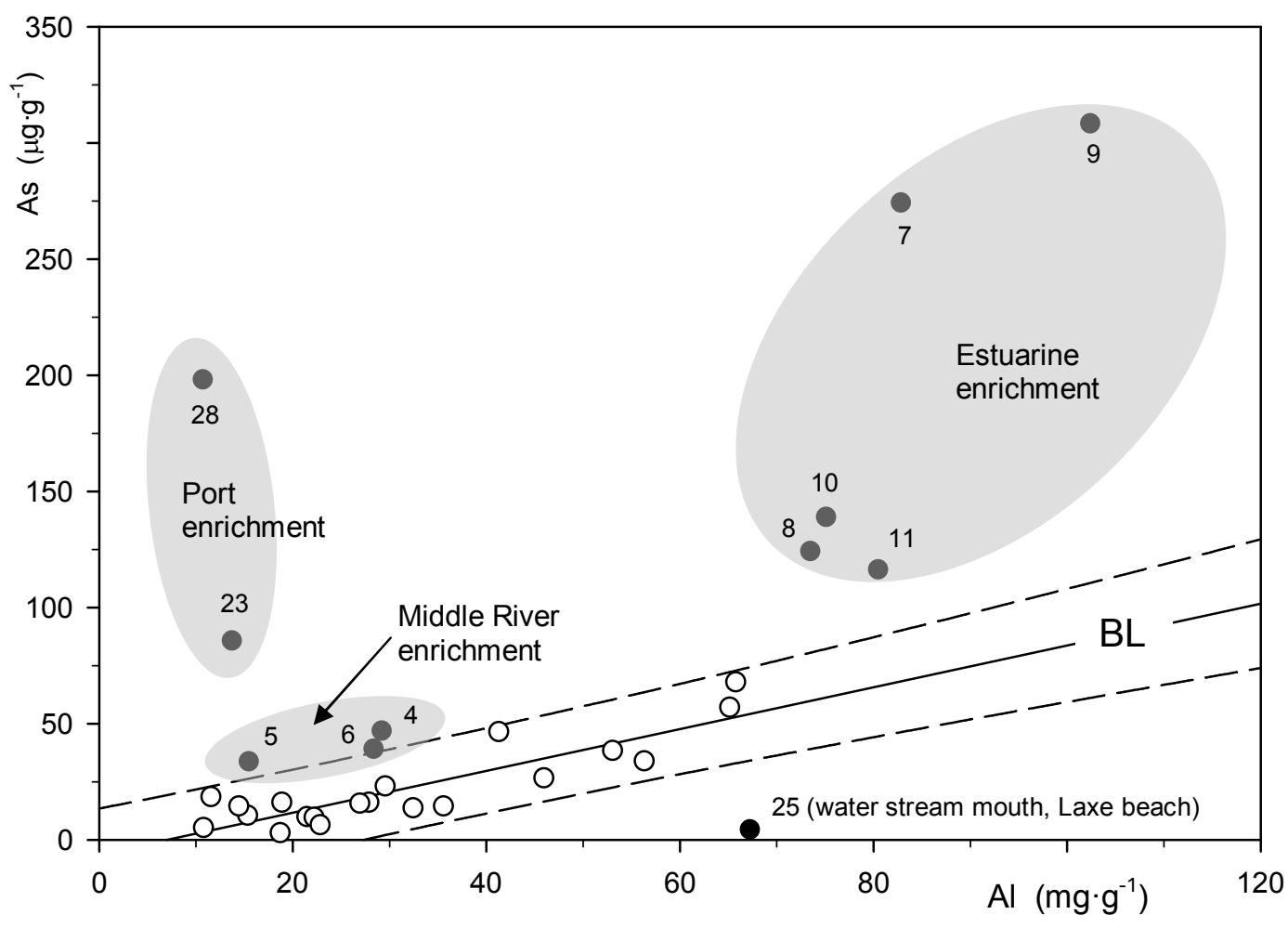

Figure 5. As-Al normalization. Background arsenic concentrations (line BL) to the river, estuary, and ria sediments (fine fraction) using aluminium as normaliser. BL was defined from the stations (empty circles) inside 95\% prediction intervals (dashed lines). Numbers of As-enriched stations (filled circles) are also included and their locations identified. 


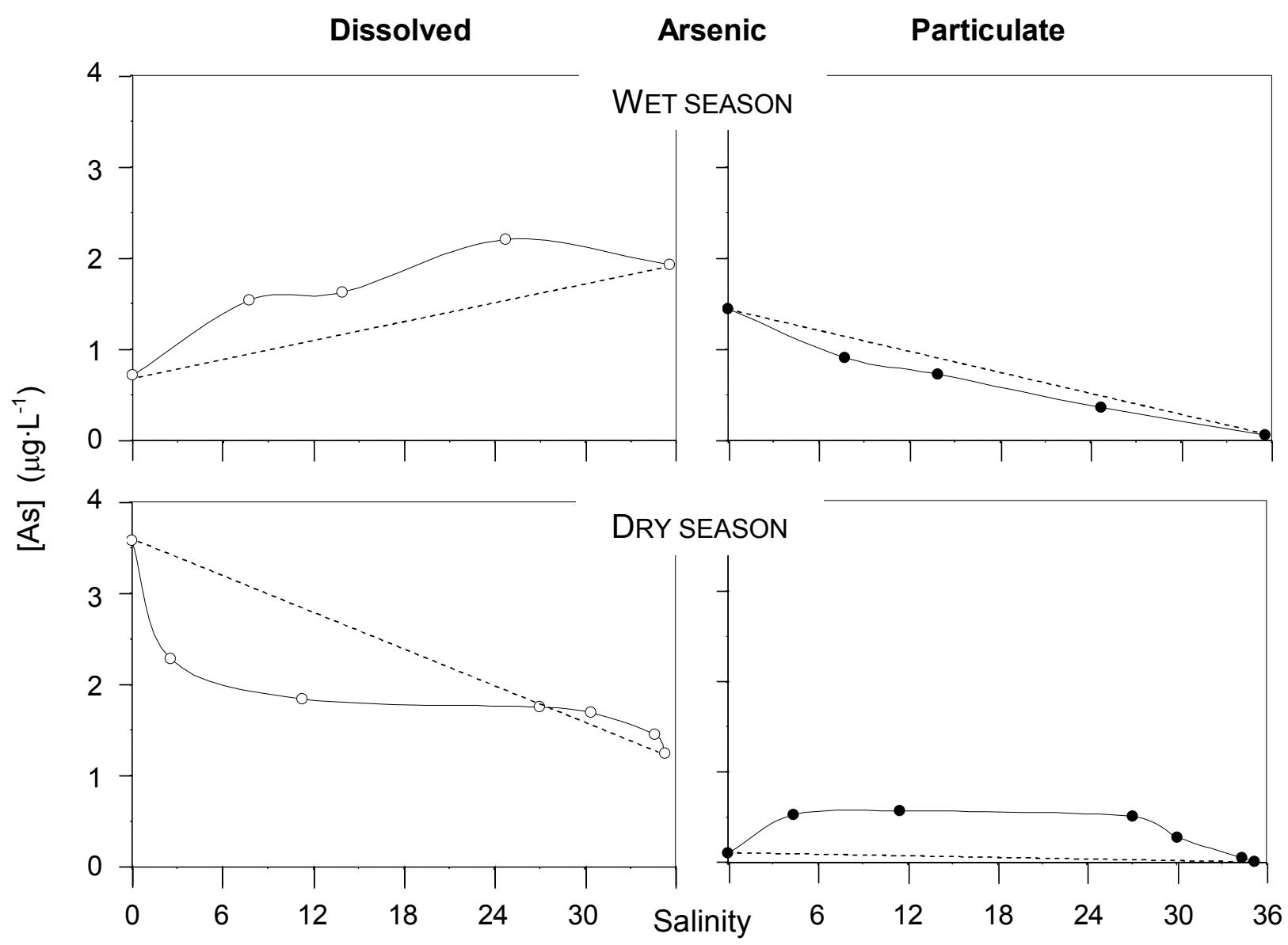

Figure 6. The annual behaviour of dissolved inorganic arsenic from the mixing curves in the Anllóns estuary: wet (January as example) and dry (July as example). Particulate arsenic behaviour is also shown (January and August). 
Table 1. The salinities in estuarine $(\mathrm{G}-\mathrm{K})$ and coastal water stations $(\mathrm{L}-\mathrm{N})$ during the sampling yearly period. The flows of Anllóns River $\left(\mathrm{m}^{3} \cdot \mathrm{s}^{-1}\right) \mathrm{measured}$ in the Anllóns gauging station (F) are also indicated. Salinities in the fluvial stations (A-E) were not shown because they match with fresh water.

\begin{tabular}{|c|c|c|c|c|c|c|c|c|c|c|c|c|}
\hline Sampling station & $\begin{array}{c}2005 \\
\text { Sept. } 28^{\text {th }} \\
\end{array}$ & Oct. $20^{\text {th }}$ & Nov. $21^{\text {st }}$ & Dec. $19^{\text {th }}$ & $\begin{array}{c}2006 \\
\text { Jan. } 16^{\text {th }}\end{array}$ & Feb. $13^{\text {th }}$ & Mar. $14^{\text {th }}$ & Apr. $3^{\text {rd }}$ & May $15^{\text {th }}$ & Jun. $12^{\text {th }}$ & Jul. $17^{\text {th }}$ & Aug. $10^{\text {th }}$ \\
\hline $\mathrm{F}$ & $<0.1$ & $<0.1$ & $<0.1$ & $<0.1$ & $<0.1$ & $<0.1$ & $<0.1$ & $<0.1$ & $<0.1$ & $<0.1$ & $<0.1$ & $<0.1$ \\
\hline $\mathrm{G}$ & 3.8 & $<0.1$ & 0.2 & 0.1 & $<0.1$ & 0.2 & $<0.1$ & $<0.1$ & 0.8 & 2.1 & 2.6 & 4.4 \\
\hline $\mathrm{H}$ & 17.9 & 0.1 & 1.0 & 0.7 & $<0.1$ & 1.7 & $<0.1$ & $<0.1$ & 1.1 & 3.3 & 11.3 & 11.5 \\
\hline 1 & 27.8 & 12.1 & 14.2 & 14.5 & 7.8 & 18.0 & 9.1 & 6.2 & 17.5 & 22.4 & 27.0 & 27.1 \\
\hline $\mathrm{J}$ & 29.3 & 25.4 & 22.8 & 27.7 & 13.9 & 23.3 & 14.2 & 9.3 & 21.6 & 28.0 & 30.4 & 30.0 \\
\hline K & 33.7 & 28.2 & 28.3 & 30.0 & 24.7 & 31.1 & 23.5 & 16.7 & 32.4 & 30.0 & 34.6 & 34.4 \\
\hline $\mathrm{L}$ & 34.9 & 28.8 & 33.8 & 31.3 & 33.2 & 32.7 & 32.5 & 29.8 & 32.4 & 34.4 & 35.0 & 35.1 \\
\hline$M$ & 34.7 & 34.4 & 34.5 & 33.2 & 34.8 & 33.8 & 33.6 & 29.5 & 34.2 & 34.1 & 35.0 & 35.1 \\
\hline $\mathrm{N}$ & 35.1 & 35.4 & 35.1 & 35.1 & 35.6 & 35.2 & 35.1 & 33.8 & 35.0 & 35.3 & 35.3 & 35.2 \\
\hline Anllóns $\left(\mathrm{m}^{3} \cdot \mathrm{s}^{-1}\right)$ & 1.50 & 16.49 & 7.62 & 7.60 & 23.63 & 6.62 & 11.76 & 17.51 & 7.11 & 5.22 & 3.17 & 1.80 \\
\hline
\end{tabular}


Table 2. The concentrations of dissolved inorganic arsenic $\left(\mu \mathrm{g} \cdot \mathrm{L}^{-1}\right)$ in river, estuarine and ria waters of the Anllóns - Laxe System during the sampling year.

\begin{tabular}{|c|c|c|c|c|c|c|c|c|c|c|c|c|c|c|c|c|c|c|c|c|c|c|c|c|c|}
\hline \multirow{3}{*}{$\frac{\text { Zone }}{\text { River }}$} & \multirow{3}{*}{$\begin{array}{c}\begin{array}{c}\text { Sampling } \\
\text { station }\end{array} \\
\mathrm{A}\end{array}$} & \multicolumn{2}{|c|}{$\begin{array}{c}2005 \\
\text { Sept. } 28^{\text {th }} \\
\end{array}$} & \multicolumn{2}{|c|}{ Oct. $20^{\text {th }}$} & \multicolumn{2}{|c|}{ Nov. $21^{\text {st }}$} & \multicolumn{2}{|c|}{ Dec. $19^{\text {th }}$} & \multicolumn{2}{|c|}{$\begin{array}{c}2006 \\
\text { Jan. } 16^{\text {th }}\end{array}$} & \multicolumn{2}{|c|}{ Feb. $13^{\text {th }}$} & \multicolumn{2}{|c|}{ Mar. $14^{\text {th }}$} & \multicolumn{2}{|c|}{ Apr. $3^{\text {rd }}$} & \multicolumn{2}{|c|}{ May $15^{\text {th }}$} & \multicolumn{2}{|c|}{ Jun. $12^{\text {th }}$} & \multicolumn{2}{|c|}{ Jul. $17^{\text {th }}$} & \multicolumn{2}{|c|}{ Aug. $10^{\text {th }}$} \\
\hline & & 0.47 & \pm & 0.74 & \pm & 0.52 & \pm & 0.55 & \pm & 0.53 & \pm & 0.29 & \pm & 0.74 & \pm & 0.46 & \pm & 1.35 & \pm & 1.31 & \pm & 1.78 & \pm & 2.30 & \pm \\
\hline & & 0.04 & & 0.07 & & 0.08 & & 0.01 & & 0.04 & & 0.09 & & 0.06 & & 0.08 & & 0.16 & & 0.03 & & 0.05 & & 0.11 & \\
\hline & B & 0.04 & & 0.05 & & 0.03 & & 0.03 & & 0.08 & & 0.06 & & 0.06 & & 0.03 & & 0.07 & & 0.06 & & 0.07 & & 0.07 & \\
\hline & \multirow{2}{*}{$C$} & 0.43 & \pm & 0.83 & \pm & 0.38 & \pm & 0.97 & \pm & 0.41 & \pm & 0.49 & \pm & 0.64 & \pm & 0.57 & \pm & 1.32 & \pm & 1.12 & \pm & 1.33 & \pm & 2.05 & \pm \\
\hline & & 0.01 & & 0.07 & & 0.06 & & 0.04 & & 0.05 & & 0.07 & & 0.03 & & 0.05 & & 0.10 & & 0.11 & & 0.02 & & 0.10 & \\
\hline & \multirow{2}{*}{$D$} & 1.73 & \pm & 0.78 & \pm & 0.49 & \pm & 1.40 & \pm & 0.56 & \pm & 0.84 & \pm & 1.53 & \pm & 1.08 & \pm & 2.44 & \pm & 2.43 & \pm & 3.33 & \pm & 3.96 & \pm \\
\hline & & 0.14 & & 0.01 & & 0.04 & & 0.07 & & 0.05 & & 0.11 & & 0.10 & & 0.07 & & 0.09 & & 0.02 & & 0.02 & & 0.07 & \\
\hline & \multirow{2}{*}{$E$} & 1.44 & \pm & 0.94 & \pm & 0.71 & \pm & 1.33 & \pm & 0.70 & \pm & 0.62 & \pm & 1.28 & \pm & 1.13 & \pm & 2.21 & \pm & 1.82 & \pm & 3.41 & \pm & 3.65 & \pm \\
\hline & & 0.17 & & 0.03 & & 0.11 & & 0.02 & & 0.05 & & 0.10 & & 0.01 & & 0.04 & & 0.08 & & 0.09 & & 0.06 & & 0.02 & \\
\hline \multirow[t]{2}{*}{ (gauging st.) } & \multirow{2}{*}{$F$} & 1.86 & \pm & 0.72 & \pm & 0.31 & \pm & 1.47 & \pm & 0.72 & \pm & 0.52 & \pm & 1.34 & \pm & 1.30 & \pm & 2.32 & \pm & 2.65 & \pm & 3.58 & \pm & 3.82 & \pm \\
\hline & & 0.16 & & 0.06 & & 0.06 & & 0.02 & & 0.04 & & 0.01 & & 0.18 & & 0.04 & & 0.07 & & 0.03 & & 0.06 & & 0.12 & \\
\hline \multirow[t]{9}{*}{ Estuary } & \multirow{2}{*}{ G } & 1.41 & \pm & 0.67 & \pm & 0.72 & \pm & 1.45 & \pm & 0.66 & \pm & 0.47 & \pm & 1.40 & \pm & 1.01 & \pm & 1.81 & \pm & 1.70 & \pm & 2.28 & \pm & 2.93 & \pm \\
\hline & & 0.14 & & 0.06 & & 0.04 & & 0.05 & & 0.04 & & 0.07 & & 0.09 & & 0.20 & & 0.03 & & 0.08 & & 0.05 & & 0.02 & \\
\hline & $\mathrm{H}$ & & & 1.17 & \pm & 1.06 & \pm & 1.04 & \pm & 0.85 & \pm & 0.52 & \pm & 1.48 & \pm & 0.83 & \pm & 1.62 & \pm & 1.30 & \pm & 1.84 & \pm & 2.95 & \pm \\
\hline & $\mathrm{H}$ & & & 0.11 & & 0.04 & & 0.04 & & 0.04 & & 0.06 & & 0.15 & & 0.11 & & 0.14 & & 0.08 & & 0.09 & & 0.09 & \\
\hline & 1 & & & 0.06 & & 0.04 & & 0.01 & & 0.08 & & 0.09 & & 0.15 & & 0.18 & & 0.11 & & 0.07 & & 0.04 & & 0.08 & \\
\hline & 1 & 0.57 & \pm & 1.18 & \pm & 0.95 & \pm & 0.52 & \pm & 1.62 & \pm & 1.16 & \pm & 1.50 & \pm & 0.97 & \pm & 2.09 & \pm & 0.71 & \pm & 1.69 & \pm & 2.41 & \pm \\
\hline & $J$ & 0.06 & & 0.04 & & 0.10 & & 0.09 & & 0.08 & & 0.14 & & 0.07 & & 0.06 & & 0.19 & & 0.04 & & 0.04 & & 0.07 & \\
\hline & $K$ & & & 1.18 & \pm & 1.59 & \pm & 0.41 & \pm & 2.20 & \pm & 1.99 & \pm & 1.56 & \pm & 1.00 & \pm & 2.48 & \pm & 1.20 & \pm & 1.45 & \pm & 1.64 & \pm \\
\hline & K & & & 0.07 & & 0.06 & & 0.04 & & 0.09 & & 0.13 & & 0.04 & & 0.05 & & 0.02 & & 0.06 & & 0.02 & & 0.01 & \\
\hline Ria & & & & 0.64 & \pm & 1.63 & \pm & 0.66 & \pm & 2.01 & \pm & 1.45 & \pm & 1.81 & \pm & 0.94 & \pm & 2.18 & \pm & 0.89 & \pm & 1.37 & \pm & 1.71 & \pm \\
\hline & L & & & 0.09 & & 0.05 & & 0.09 & & 0.07 & & 0.09 & & 0.03 & & 0.13 & & 0.05 & & 0.09 & & 0.07 & & 0.06 & \\
\hline & & 0.30 & \pm & 0.40 & \pm & 1.71 & \pm & 0.47 & \pm & 2.03 & \pm & 1.81 & \pm & 2.05 & \pm & 0.76 & \pm & 2.60 & \pm & 0.80 & \pm & 1.51 & \pm & 1.44 & \pm \\
\hline & $\mathrm{IVI}$ & 0.03 & & 0.04 & & 0.06 & & 0.13 & & 0.11 & & 0.01 & & 0.12 & & 0.08 & & 0.06 & & 0.08 & & 0.02 & & 0.09 & \\
\hline & $N$ & & & 0.83 & \pm & 1.24 & \pm & 0.55 & \pm & 1.93 & \pm & 1.89 & \pm & 2.25 & \pm & 0.68 & \pm & 2.18 & \pm & 0.77 & \pm & 1.24 & \pm & 1.66 & \pm \\
\hline & IN & & & 0.01 & & 0.08 & & 0.01 & & 0.18 & & 0.09 & & 0.16 & & 0.04 & & 0.06 & & 0.11 & & 0.06 & & 0.10 & \\
\hline
\end{tabular}


Table 3. The arsenic concentrations $\left(\mathrm{mg}^{\mathrm{kg}} \mathrm{k}^{-1}\right)$ in the suspended particulate matter (SPM) filtered from the water sampled at stations A-N (see Fig.1). The whole of stations were sampled at three different river flow patterns: January $\left(24 \mathrm{~m}^{3} \cdot \mathrm{s}^{-1}\right)$, March $\left(12 \mathrm{~m}^{3} \cdot \mathrm{s}^{-1}\right)$ and August $\left(2 \mathrm{~m}^{3} \cdot \mathrm{s}^{-1}\right)$. St.B corresponds to the pristine watercourse; St.E is situated after the Corcoesto zone; St.F is in the river gauging station (in brackets are indicated the SPM concentrations in $\mathrm{mg} \cdot \mathrm{L}^{-1}$ ); St. $\mathrm{H}$ in the fluvial bridge of the Ponteceso town; and St.K in the Anllóns estuary mouth (see Fig.1).

\begin{tabular}{|c|c|c|c|c|c|c|c|c|c|c|c|c|c|}
\hline Zone & $\begin{array}{l}\text { Sampling } \\
\text { station }\end{array}$ & $\begin{array}{c}2005 \\
\text { Sept. } 28^{\text {th }}\end{array}$ & Oct. $20^{\text {th }}$ & Nov. $21^{\text {st }}$ & Dec. $19^{\text {th }}$ & $\begin{array}{c}2006 \\
\text { Jan. } 16^{\text {th }}\end{array}$ & Feb. $13^{\text {th }}$ & Mar. $14^{\text {th }}$ & Apr. $3^{\text {rd }}$ & May $15^{\text {th }}$ & Jun. $12^{\text {th }}$ & Jul. $17^{\text {th }}$ & Aug. $10^{\text {th }}$ \\
\hline \multirow[t]{5}{*}{ River } & $A$ & & & & & $65.3 \pm 2.7$ & & $48.2 \pm 0.5$ & & & & & $21.2 \pm 2.2$ \\
\hline & B & $57.5 \pm 1.4$ & $41.2 \pm 0.1$ & $74.8 \pm 0.8$ & $61.5 \pm 1.6$ & $50.0 \pm 2.8$ & $51.9 \pm 1.7$ & $52.1 \pm 1.8$ & $44.3 \pm 1.1$ & $60.1 \pm 1.3$ & $52.7 \pm 1.8$ & $32.8 \pm 0.6$ & $36.6 \pm 0.2$ \\
\hline & C & & & & & $58.4 \pm 1.7$ & & $67.3 \pm 2.0$ & & & & & $96.0 \pm 3.5$ \\
\hline & D & & & & & $77.8 \pm 3.2$ & & $70.6 \pm 0.8$ & & & & & $180.9 \pm 1.8$ \\
\hline & $E$ & $151.7 \pm 2.5$ & $44.3 \pm 0.7$ & $92.2 \pm 0.6$ & $100.3 \pm 1.3$ & $72.8 \pm 1.6$ & $85.5 \pm 2.5$ & $82.6 \pm 2.9$ & $99.9 \pm 2.8$ & $134.0 \pm 4.0$ & $123.1 \pm 4.4$ & $115.6 \pm 5.1$ & $140.8 \pm 4.1$ \\
\hline (gauging st.) & $\mathrm{F}$ & $\begin{array}{c}95.2 \pm 2.7 \\
(1.3)\end{array}$ & $\begin{array}{c}52.8 \pm 0.4 \\
(53.9)\end{array}$ & $\begin{array}{c}120.2 \pm 3.2 \\
(2.5)\end{array}$ & $\begin{array}{c}89.7 \pm 1.4 \\
(3.2)\end{array}$ & $\begin{array}{c}92.6 \pm 2.0 \\
(20.2)\end{array}$ & $\begin{array}{c}128.3 \pm 1.9 \\
(1.9)\end{array}$ & $\begin{array}{c}98.4 \pm 3.0 \\
(6.3)\end{array}$ & $\begin{array}{c}91.5 \pm 2.3 \\
(9.0)\end{array}$ & $\begin{array}{c}126.4 \pm 3.2 \\
(2.4)\end{array}$ & $\begin{array}{c}145.3 \pm 5.1 \\
(1.8)\end{array}$ & $\begin{array}{c}169.0 \pm 5.3 \\
(1.0)\end{array}$ & $\begin{array}{c}104.5 \pm 4.6 \\
(1.0)\end{array}$ \\
\hline \multirow[t]{5}{*}{ Estuary } & G & & & & & $79.9 \pm 5.8$ & & $88.6 \pm 1.1$ & & & & & $115.7 \pm 0.4$ \\
\hline & $\mathrm{H}$ & $96.2 \pm 0.1$ & $70.1 \pm 0.5$ & $187.2 \pm 4.1$ & $201.6 \pm 2.6$ & $92.7 \pm 0.3$ & $138.0 \pm 4.9$ & $95.9 \pm 3.2$ & $90.1 \pm 3.3$ & $114.5 \pm 1.3$ & $93.9 \pm 0.8$ & $128.2 \pm 1.4$ & $100.3 \pm 0.1$ \\
\hline & 1 & & & & & $104.4 \pm 3.8$ & & $93.8 \pm 0.4$ & & & & & $62.7 \pm 0.3$ \\
\hline & J & & & & & $73.2 \pm 0.9$ & & $65.2 \pm 0.1$ & & & & & $93.5 \pm 1.0$ \\
\hline & K & $49.0 \pm 0.4$ & $87.2 \pm 3.8$ & $220.0 \pm 4.0$ & $6.0 \pm 0.2$ & $73.2 \pm 0.5$ & $27.5 \pm 1.1$ & $21.3 \pm 1.4$ & $63.4 \pm 1.6$ & $46.4 \pm 3.0$ & $19.3 \pm 0.5$ & $29.3 \pm 3.3$ & $30.9 \pm 0.2$ \\
\hline \multirow[t]{3}{*}{ Ria } & $\mathrm{L}$ & & & & & $7.5 \pm 0.2$ & & $8.8 \pm 0.1$ & & & & & $12.7 \pm 0.3$ \\
\hline & M & & & & & $27.9 \pm 0.1$ & & $40.1 \pm 0.6$ & & & & & $25.5 \pm 1.0$ \\
\hline & $\mathrm{N}$ & & & & & $12.9 \pm 0.3$ & & $7.1 \pm 0.7$ & & & & & $2.8 \pm 0.6$ \\
\hline
\end{tabular}


Table 4. The iron $\left(\mathrm{g} \cdot \mathrm{kg}^{-1}\right)$, arsenic $\left(\mathrm{mg} \cdot \mathrm{kg}^{-1}\right)$ and aluminium $\left(\mathrm{g} \cdot \mathrm{kg}^{-1}\right)$ concentrations in the fine surface sediments of the Anllóns-Laxe System. Background level of arsenic, $[A s]_{\mathrm{BV}}$, in each station was calculated applying $\mathrm{As} / \mathrm{Al}$ equation (1). Arsenic enrichment factors, $\mathrm{EF}_{\mathrm{As}}$, were quantified according to the equation (2).

\begin{tabular}{|c|c|c|c|c|c|}
\hline Station & {$[\mathrm{Fe}]$} & {$[\mathrm{Al}]$} & [As] & {$[\mathrm{As}]_{\mathrm{BV}}$} & $\mathrm{EF}_{\mathrm{As}}$ \\
\hline \multicolumn{6}{|c|}{ Anllóns River } \\
\hline 1 & & 32.5 & $13.6 \pm 0.5$ & 22.9 & 0.6 \\
\hline 2 & & 27.9 & $16.1 \pm 0.3$ & 18.8 & 0.9 \\
\hline 3 & & 29.6 & $23.1 \pm 0.4$ & 20.3 & 1.1 \\
\hline 4 & & 15.5 & $33.7 \pm 0.6$ & 20.0 & 2.3 \\
\hline 5 & & 29.3 & $46.9 \pm 0.2$ & 7.6 & 4.4 \\
\hline 6 & & 28.4 & $39.1 \pm 1.8$ & 19.2 & 2.0 \\
\hline \multicolumn{6}{|c|}{ Anllóns Estuary } \\
\hline 7 & 51.3 & 82.8 & $274.2 \pm 4.8$ & 68.3 & 4.0 \\
\hline 8 & 49.2 & 73.5 & $124.2 \pm 4.8$ & 59.8 & 2.1 \\
\hline 9 & 43.4 & 102.4 & $308.3 \pm 2.5$ & 85.9 & 3.6 \\
\hline 10 & 48.4 & 75.1 & $138.9 \pm 2.9$ & 61.3 & 2.3 \\
\hline 11 & 44.5 & 80.5 & $116.3 \pm 0.8$ & 66.2 & 1.8 \\
\hline 12 & 46.3 & 65.8 & $67.9 \pm 2.9$ & 52.9 & 1.3 \\
\hline 13 & 30.2 & 41.3 & $46.5 \pm 0.8$ & 30.9 & 1.5 \\
\hline 14 & 22.2 & 53.2 & $38.4 \pm 2.0$ & 41.5 & 0.9 \\
\hline 15 & 8.0 & 27.0 & $15.7 \pm 0.7$ & 18.0 & 0.9 \\
\hline 16 & 26.0 & 56.3 & $33.9 \pm 0.2$ & 44.4 & 0.8 \\
\hline 17 & 19.6 & 46.0 & $26.6 \pm 0.4$ & 35.1 & 0.8 \\
\hline 18 & 32.7 & 65.2 & $57.0 \pm 0.2$ & 52.4 & 1.1 \\
\hline \multicolumn{6}{|c|}{ Ria of Laxe } \\
\hline 19 & 1.5 & 10.8 & $5.2 \pm 0.2$ & 3.4 & 1.5 \\
\hline 20 & 16.0 & 14.6 & $18.5 \pm 1.4$ & 6.8 & 2.7 \\
\hline 21 & 15.7 & 15.4 & $10.5 \pm 1.4$ & 7.5 & 1.4 \\
\hline 22 & 28.4 & 14.5 & $14.5 \pm 0.3$ & 6.7 & 2.2 \\
\hline 23 & 7.8 & 13.7 & $85.7 \pm 2.6$ & 6.1 & 14.1 \\
\hline 24 & 17.7 & 22.9 & $6.4 \pm 0.3$ & 14.3 & 0.5 \\
\hline 25 & 5.3 & 67.3 & $4.4 \pm 0.3$ & 54.2 & 0.1 \\
\hline 26 & 10.0 & 22.2 & $9.6 \pm 1.5$ & 13.7 & 0.7 \\
\hline 27 & 30.5 & 35.6 & $14.5 \pm 1.9$ & 25.7 & 0.6 \\
\hline 28 & 5.1 & 10.7 & $198.1 \pm 9.7$ & 3.4 & 58.8 \\
\hline 29 & 19.5 & 21.5 & $9.9 \pm 1.0$ & 13.1 & 0.8 \\
\hline 30 & 17.6 & 18.9 & $16.1 \pm 0.1$ & 10.7 & 1.5 \\
\hline
\end{tabular}

